\title{
The standard-setters' toolkit: can principles prevail over bright lines?
}

\author{
Darren Henderson $^{1}$ • Patricia C. O'Brien ${ }^{2}$
}

Published online: 5 May 2017

C The Author(s) 2017. This article is published with open access at Springerlink.com

\begin{abstract}
We study lease accounting in an international panel data set to examine how accounting outcomes vary with two features of accounting standards: the emphasis on using professional judgement to apply principles, and the presence or absence of bright-line tests. We study four countriesAustralia, Canada, the UK, and the US-and companies in two leaseintensive industries-retail and transportation. Our primary study period spans the time when Australia and the UK switched from domestic to international accounting standards, and in one test, we also consider Canada's transition to international standards. We find that neither an explicit requirement to apply a principle nor omitting bright-line tests materially increases the use of capital lease treatment among these firms. Overall, we conclude that this financial reporting outcome is relatively insensitive to these standard-setting tools.
\end{abstract}

Keywords Principles-based standards · Rules-based standards · Lease accounting • Bright lines · IFRS

JEL Classification M41 $\cdot$ M48

Patricia C. O’Brien

pobrien@uwaterloo.ca

Darren Henderson

dhenderson@wlu.ca

1 Lazaridis School of Business \& Economics, Wilfrid Laurier University, Waterloo, ON, Canada

2 School of Accounting and Finance, University of Waterloo, Waterloo, ON, Canada 
One of my great ambitions before I die is to fly in an aircraft that is on an airline's balance sheet. - Sir David Tweedie ${ }^{1}$

\section{Introduction}

Standard-setters have long recognized leasing transactions as a potential threat to fair presentation of a company's financial position. In 1976, the Financial Accounting Standards Board's (FASB) FAS13 introduced capital lease treatment to account for leases that resemble outright purchases, while IAS17 featured similar treatment in $1982 .^{2}$ Many US companies responded to FAS13 by altering their lease contracts to avoid capital lease accounting, retaining leased assets' off-balance-sheet status (Imhoff and Thomas 1988). Furthermore, entire industries arose solely to structure lease contracts that avoid capital lease treatment (Securities Exchange Commission, (SEC) 2008, p. 41). Most observers trace these outcomes to FAS13's specific guidance, which gave companies a clear road map for designing contracts. Our opening quote from Sir David Tweedie accompanied his call for an overhaul of lease accounting standards to ensure that leased assets appear on balance sheet. ${ }^{3}$

We study two aspects of accounting standards that may affect lease accounting outcomes. First, we study whether including in the standard "a concise statement of substantive accounting principle" (SEC 2003, section I.C.) promotes lease capitalization; our evidence does not support this view. Second, we examine whether removing bright lines tempers or reverses the substitution away from capital leases that Imhoff and Thomas (1988) documented. We examine both overall use of capital leases and details of the operating leases that presumably have been structured to stay off balance sheet. We find cases where companies increased capitalized leases after IFRS removed brightline tests, but the economic importance across sample firms is small. We find no evidence that removing bright lines caused companies to change how they structure their operating leases. Overall, we interpret our findings to say that bright lines had a robust and durable influence on lease accounting practice, even in the strongest enforcement regimes in the world, and that neither emphasizing the principle nor removing bright line tests materially affected outcomes.

The idea that clear, enforceable rules create opportunities to structure contracts that evade the rules is an accepted precept of accounting standard-setting, often leading to calls for standards written as general principles without bright-line tests (Maines et al. 2003; SEC 2003; 2008). Nelson (2003), on the other hand, cites a large body of survey and experimental evidence suggesting that imprecise accounting standards can encourage aggressive reporting by offering more room for interpretation and negotiation. Similarly, Livne and McNichols (2009) provide evidence suggesting that,

\footnotetext{
${ }^{1}$ See Tweedie (2008). Sir David Tweedie was chairman of the International Accounting Standards Board (IASB) from 2001 to 2011.

${ }^{2}$ FAS13 refers to the US Statement of Financial Accounting Standards No. 13, "Accounting for Leases." IAS17 refers to International Accounting Standard 17, "Leases."

${ }^{3}$ In January 2016, the International Accounting Standards Board (IASB) released IFRS 16: "Leases." In February 2016, the FASB released "Topic 842: Leases." Both standards place most leases on balance sheet and will be effective in 2019.
} 
in the case of the UK "true and fair view override," firms used overriding principles opportunistically. Nelson (2003) and Jamal and Tan (2010) call for empirical analysis of the effects of principles-based standards on companies' accounting choices. Our study answers those calls by examining leasing outcomes in practice.

We study the lease accounting choices of lessee firms in four countries: Australia, Canada, the UK, and the US. As we explain in greater detail below, the accounting regimes differ in whether the lease standard emphasizes the "substantive accounting principle" requiring the application of professional judgement, and also in the existence and particulars of the bright-line tests. This cross-sectional variation in accounting regimes provides an opportunity to study the impact of these standard-setting tools on observed lease capitalization outcomes. We further examine pre- versus post-IFRS lease accounting in Australia, Canada and the UK, which allows us to examine regime change, holding the country constant.

All international research faces challenges due to the impossibility of creating true ceteris paribus conditions, given enduring and influential country-specific characteristics. Any country-specific traits other than accounting regime that affect companies' accounting decisions, from legal systems to cultural norms, can confound inferences. As we explain further in Section 3, we select our four countries to provide a relatively homogeneous setting on non-accounting dimensions, which nonetheless retains crosssectional and time-series variation in lease accounting standards. Furthermore, to control for the nature of the leased assets, we limit our analyses to two leaseintensive industries: retail and transportation.

Observers outside the US generally regard the US as unique in its emphasis on rules. Kershaw (2005), for example, describes a "widespread consensus" in the UK about the superiority of its accounting standards over the rules-based US (p. 595). This view persists, despite identical guidance or the frequent practice of using US guidance when local standards provide none. In this view, requiring the preparer or auditor to exercise professional judgment to apply a general principle makes a standard "principles-based." In contrast, Schipper (2003) and Nelson (2003), reflecting a view that is often expressed within the US, describe US standards as generally principles-based, with gradations of guidance tending toward rules as the guidance becomes more specific.

In the US, FAS13 provided strict bright-line criteria that allowed no principles-based override in determining the accounting treatment of a lease. Imhoff and Thomas (1988) convincingly demonstrate that US companies changed the way they wrote contracts following FAS13, substantially increasing companies' use of operating leases, the opposite of the standard's intent. Since then, FAS13 has served as the key example of how rules and bright lines promote transaction structuring and circumvention, rather than informative accounting. In the UK, Beattie et al. (2006) find that both users and preparers identify the potential for deliberate transaction structuring as the key deficiency in lease standards.

Before adopting IFRS, Australia, Canada, and the UK had lease accounting standards with similar or identical bright-line guidance to that in FAS13, but the standards contained an overriding principle and a requirement for professionals to judge whether the risks and rewards of ownership had effectively transferred. Our first hypothesis tests whether including this overriding principle affected the accounting outcomes in these countries, relative to the US. In particular, we test whether similar companies leasing similar, economically 
important assets report their leases as capital leases when standards encourage professional judgment of principles, rather than application of rules.

Although we find that capital lease use varies significantly across our sample countries, overall the US is not distinct or unusual in avoiding capital leases. The US appears similar to Canada and the UK in both industries. We find significantly higher capital lease use in Australia than in the US, consistent with the hypothesis that emphasizing the principle promotes capital lease use. Australia is equally distinct from Canada and the UK, however, and those two countries had the same emphasis on principle. Overall, this evidence does not support the notion that explicitly stating the principle in the standard promotes capital lease use.

Our second hypothesis considers whether removing bright-line tests affects lease capitalization. For this analysis, we restrict attention to the countries that emphasized the overriding principle in their pre-IFRS lease standards: Australia, Canada, and the UK. These three countries all adopted IFRS during the period when IAS17 retained the risks and rewards principle, while removing bright-line guidance. ${ }^{4}$ Australia and the UK adopted IFRS in 2005, while Canada adopted in $2011 .^{5}$ In theory, the uncertainty created by eliminating guidance could weigh in either direction, either loosening restrictions or constraining aggressive behavior (Nelson 2003). If eliminating bright lines promotes lease capitalization, we should see more capital lease use under IAS17. On the other hand, if companies continue to adhere to past guidance or employ US guidance to fill the void, or if the bright line guidance approximates the true conditions for transfer of risks and rewards, then we should expect no change in capital lease use.

We consider three different contrasts relating to IFRS. First, we conduct a time-series test comparing pre- versus post-IAS17 lease treatment in Australia and the UK. These tests do not find significant changes in lease classification around 2005. Second, we conduct a difference-in-differences test of Canada versus Australia and the UK, between 2003 and 2007. Canada, on domestic GAAP, serves as a period control when Australia and the UK switch to IFRS. These tests find no statistically significant differences; the results in transportation have the predicted direction, while those in retail do not.

Our third analysis of this hypothesis looks for accounting changes in the IFRS transition year, within firm. Because IFRS requires firms to restate their opening balance sheets in the transition year, we can hold the lease contracts constant and examine the accounting choices each firm makes under the domestic GAAP standard versus IAS17. We find some firms reclassifying operating leases to capital and none reclassifying capital to operating, supporting the idea that eliminating guidance promotes greater lease capitalization; the overall effect of the reclassifications, however, is small.

Our third and fourth hypotheses explore whether transaction structuring to achieve operating lease treatment varies across our countries. In $\mathrm{H} 3$ we conjecture that companies in regimes with bright lines relating to the assets' useful life will, ceteris paribus,

\footnotetext{
${ }^{4}$ Using Mergenthaler's (2009) measure of the extent to which a given standard is rules-based, Donelson et al. (2012) evaluate FAS13 at the highest possible score of 4, while IAS17, which includes no bright-line tests, merits a score of 2.

${ }^{5}$ Specifically, 2005 and 2011 are the adoption years for December fiscal year-end companies. Companies with other fiscal year-ends generally had the effective date in the following calendar year. For simplicity, we refer to the transition year as "2005" for Australia and the UK and "2011" for Canada.
} 
structure their operating leases to be shorter. Data limitations prevent our testing the UK pre-2005, when it was the sole regime without the useful-life bright line. Post-2005, however, UK retail firms have significantly longer operating lease terms than industry peers in our comparison countries. Conceivably, transaction-structuring via the lease term did not take hold in the UK because of the lack of bright-line guidance on that trait. No other countries' lease terms changed significantly between 2003 and 2007, suggesting no industry or global trend toward longer leases. Australian firms have shorter, not longer, lease terms post-2005 than industry peers in Canada or the US. Overall, we find no support for the hypothesis that eliminating the useful-life bright line reduced transaction structuring via the lease term.

In $\mathrm{H} 4$, we hypothesize that companies in regimes with bright lines relating to the present value of lease payments will use more contingent rentals, to reduce reported minimum lease payments. We find no significant change in Australian and UK firms' use of contingent rentals after they adopt IAS17, and the direction of change is opposite the prediction of reduced transaction structuring. Overall, we find no evidence that eliminating the present value bright line reduced the use of contingent rentals.

We find many significant differences across regimes but little evidence to support the ideas that either (a) encouraging professionals to apply a principle over and above bright-line guidance or (b) eliminating bright lines from standards reduces transaction structuring to avoid capital leases. Overall, we believe our evidence is consistent with country-specific characteristics trumping differences in accounting standards. Such characteristics may contribute to inertia in the face of accounting standard changes, especially when standards continue to allow prior practice. ${ }^{6}$

We explore potential confounding factors, including contract differences and tax law changes, and find some anecdotal explanations that fit individual circumstances but no general drivers. For example, Australian companies unexpectedly use markedly more capital leases than their industry peers in the other three countries. This is in part due to the common Australian business practice of using hire purchase contracts, which transfer ownership at the end of the lease. UK firms also use hire purchase contracts, but their capital lease use is minimal, so the anecdotal explanation does not generalize, even within our sample countries. Our research design, which exploits variation across regimes in accounting standards while limiting variation in non-accounting traits, constrains our subsequent investigation of unanticipated variation across regimes. A full exploration of these unanticipated phenomena requires a new sample and a design chosen to illuminate those phenomena.

Our study is subject to other limitations. Because we must hand-collect much of our data and wish to conduct analyses within-industry, we limit our analysis to two industries in which leasing is economically important, with leased assets that are fundamental to operations. We find substantial variation in practice between the two industries, confirming that results from one industry may not generalize to others. Similarly, limiting our analysis to four OECD-member, primarily English-speaking

\footnotetext{
${ }^{6}$ For example, in their post-implementation review of IFRS 8, "Operating Segments," the IASB commented that some companies simply carried on with their existing reporting even after a new standard was introduced. See http://www.ifrs.org/Current-Projects/IASB-Projects/PIR/IFRS-8/Documents/PIR-IFRS-8-OperatingSegments-July-2013.pdf, accessed Sept. 17, 2015. We thank a reviewer for this insight and example.
} 
countries with strong legal institutions and regulation helps control for cross-country differences but also limits generalization to other countries. Finally, enforcement, interpretation of standards, and economic conditions change over time. Thus our results may not generalize to other periods.

The paper proceeds as follows. In Section 2, we discuss relevant background and form our hypotheses. In Section 3, we discuss our data and measurement choices. In Section 4, we discuss our results. In Section 5, we conclude.

\section{Background and hypothesis development}

\subsection{Lease standards}

Capital lease accounting makes companies appear more highly levered than the alternative, operating lease treatment; hence many companies seek operating treatment for their leases. ${ }^{7}$ Firms with growing lease activity report lower income under capital lease treatment (ceteris paribus), providing another, albeit temporary, advantage to operating lease treatment. On the other hand, firms can report consistently higher operating cash flow under capital lease treatment, because they classify a significant portion of the lease payment as repaid borrowing. Standard-setters have been most concerned with concealed leverage and have attempted to curtail the use of operating leases. Consistent with the notion of concealed leverage, credit rating agencies use pro forma capitalization of operating leases in their risk assessments. ${ }^{8}$ While underlying business and economic factors certainly affect lease terms, evidence from the literature (notably, Imhoff and Thomas 1988) suggests that financial reporting considerations also play a role.

Much research on lease accounting focuses on how lease capitalization affects financial statements and ratios (e.g., Ashton 1985; Imhoff et al. 1991; Imhoff et al. 1993; Beattie et al. 1998; Bennett and Bradbury 2003), and whether financial statement users impound off-balance-sheet lease information (e.g., Bowman 1980; Imhoff et al. 1993; Ely 1995; Beattie et al. 2000a; Beattie et al. 2000b). Generally, that research shows that financial statements can appear dramatically different in heavy leasing industries, and that most users are not fooled by off-balance-sheet treatment.

Public statements like our opening quote from a former IASB chair, along with written justifications for pre-2016 lease standards, indicate that standard-setters perceive off-balance-sheet leases to be a problem. On-balance-sheet representation is the clear goal of the recent project that replaced IAS17 with IFRS16 ${ }^{9}$ :

\footnotetext{
7 Some jurisdictions use the terms "finance lease" or "financing lease" for contracts that transfer substantially all risks and rewards to the lessee. We treat these terms as interchangeable with "capital lease." To avoid confusion, we consistently use "capital lease" to describe accounting that results in leased assets and lease liabilities appearing on the lessee's balance sheet.

${ }^{8}$ See, for example, Moody's Investors Service (2006) and evidence provided by Altamuro et al. (2014).

${ }^{9}$ http://www.fasb.org/cs/ContentServer?c=FASBContent_C\&pagename=FASB\%2FFASBContent_C\%2 FProjectUpdatePage $\&$ cid=900000011123\#objective, accessed June 16, 2014. See also FAS13, paragraphs 63 $-71$.
} 
The objective of the project is to increase transparency and comparability among organizations by recognizing lease assets and liabilities on the balance sheet and disclosing key information. This represents an improvement over existing leases standards, which do not require lease assets and lease liabilities to be recognized by many lessees.

Standard-setters' statements like the above motivate our examination of two tools employed toward this end: stating an overarching principle within the standard, and eliminating bright-line guidance. ${ }^{10}$

In the US, FAS13 applies a rule: lessee companies must use capital lease accounting for noncancellable leases that meet any of four criteria, and must use operating lease accounting otherwise. Two of these criteria employ quantitative bright lines: the lease term be at least $75 \%$ of the asset's useful life, and the present value of minimum lease payments be at least $90 \%$ of the asset's fair market value at lease inception. The standard can be interpreted as principlesbased, but the statement of principle appears outside the body of the standard, in the background section. ${ }^{11}$

The pre-IFRS Canadian CICA Handbook section 3065, and Australian standard AASB1008: "Leases" contain precisely the same four criteria as the US standard, but presented as guidance. The standards emphasize that the accountant must exercise professional judgment to decide whether a lease transfers "substantially all the risks and rewards" of ownership. ${ }^{12}$ The UK's Statement of Standard Accounting Practice (SSAP) 21: "Accounting for Leases and Hire Purchase Contracts" includes the fair value test but omits the useful life test. Like the Australian and Canadian standards, it requires the use of professional judgement to apply the risks and rewards principle. ${ }^{13}$ In contrast, IAS17 indicates that leases transferring "substantially all" risks and rewards should be treated as capital leases but declines to state any bright-line criteria for determining whether the transfer has occurred. ${ }^{14}$ See Fig. 1 for a summary of standards across regimes.

\subsection{H1: firms use more capital leases when the standard emphasizes the principle}

Outside the US, standard-setters and educators stress that professional judgement should prevail, even when quantitative bright lines are satisfied. Beechy and Conrod (2008), for example, draw a clear distinction between the Canadian standard and its US counterpart in their textbook ${ }^{15}$.

\footnotetext{
${ }^{10}$ The FASB's 2013 Exposure Draft "Leases" (Topic 842) states: "The requirements in this Exposure Draft do not depend on significant bright-line or percentage tests. Current U.S. GAAP includes several bright-line tests, and the Board consciously attempted not to include bright lines in the new requirements" (BC335).

${ }^{11}$ FAS13, paragraphs 7 and 60 .

12 CICA HB section 3065.6, and AASB1008, section 5.

${ }^{13}$ SSAP21, paragraphs 15,16 , and 32 .

${ }^{14}$ IAS17, paragraphs 7, 8, and 12 .

${ }^{15}$ We found this emphasis on the principle in textbooks with only Canadian authors. Interestingly, the Canadian edition of a popular US intermediate accounting textbook emphasizes the criteria, with the principle stated as background.
} 


\begin{tabular}{|l|c|c|c|c|c|}
\hline & US & AUS & CDA & UK & IFRS \\
\hline Strict rule for lease accounting & $\sqrt{ }$ & & & & \\
\hline $\begin{array}{c}\text { Emphasis of principal in } \\
\text { applying guidance }\end{array}$ & $\sqrt{ }$ & $\sqrt{ }$ & $\sqrt{ }$ & $\sqrt{ }$ \\
\hline $\begin{array}{c}\text { Bright line for lease term > } \\
75 \% \text { of life }\end{array}$ & $\sqrt{ }$ & $\sqrt{ }$ & $\sqrt{ }$ & & \\
\hline $\begin{array}{c}\text { Bright line for present value }> \\
90 \% \text { of fair market value }\end{array}$ & $\sqrt{ }$ & $\sqrt{ }$ & $\sqrt{ }$ & $\sqrt{ }$ & \\
\hline
\end{tabular}

Fig. 1 Key lease accounting differences across regimes

In Canada, these criteria are only guidelines; the basic criterion is judgemental: $d o$ the terms of the lease transfer substantially all of the benefits and risks of ownership from the lessor to the lessee?... The U.S. FASB has the same criteria, but they are rules; if any one of the criteria is satisfied, then the lease must be reported as a capital lease (1009, emphasis in original).

An anecdote supporting this difference in perspective appears in the US GAAP reconciliation footnote for a Canadian firm cross-listed in the US, Canadian Pacific Railway. From 2007 to 2009, this company classified between CDN \$8.7 million and $\$ 10.4$ million (2.3-3.8\% of total capital leases) as capital leases under Canadian GAAP but as operating leases under US GAAP, due to the strict application of quantitative guidance in the US.

To study whether this difference in perspective materially affects accounting outcomes, we compare the US to Australia, Canada, and the UK. If requiring professionals to apply an overriding principle leads to less transaction structuring by companies or to a different interpretation of the point where risks and rewards transfer, then we expect more capital lease use in the other three regimes, relative to the US. In alternative form, our first hypothesis is as follows.

\section{H1: Firms in regimes that emphasize professional judgment in applying princi-} ples report more capital leases than US firms.

Alternatively, if professionals in different regimes use bright-line guidance similarly, then we expect no difference in capital lease use. ${ }^{16}$ This could occur, for example, if international auditors standardize practice advice across jurisdictions or if auditors believe that the bright-line criteria fairly reflect the principle. Cohen et al. (2013) find, in an experimental setting with bright-line tests, that auditors are more likely to require capitalization when the standard contains a professional judgement clause. Nelson et al. (2002) report that auditors believe that firms use transaction structuring less under principles-based standards but also note that less precise standards can create room for auditor-client negotiation to achieve client reporting goals. Our evidence on actual outcomes complements the experimental and survey evidence.

\footnotetext{
${ }^{16}$ Although we state directional hypotheses for clarity, we argue for substantial doubt about the direction of effects and, in fact, frequently find contrary evidence. We therefore report two-tailed $p$-values for all statistical tests.
} 


\subsection{H2: eliminating bright lines promotes capital lease treatment}

We next examine whether removing bright lines affects lease accounting choices. Imhoff and Thomas (1988) found that FAS13 provided companies with the parameters to avoid capitalization. With H2, we examine the reverse situation. Agoglia et al. (2011) and Jamal and Tan (2010) provide evidence that experimental participants (US CFOs and Canadian financial managers, respectively) are more likely to capitalize a lease when bright lines are absent than when they are present. We thus offer the following conjecture.

\section{H2: Firms report more capital leases when bright lines are omitted from the standard.}

An important difference between our setting and the one examined by Imhoff and Thomas (1988) is that our change occurs after a sustained period in which accounting practice accepted leases that were specifically structured to achieve operating treatment. We characterize Imhoff and Thomas' question as: when given bright lines, do firms use them to avoid capitalizing leases? In H2, we ask two questions. (1) Once bright lines are established, can removing them from accounting standards reverse their effect? (2) Will companies classify identical lease contracts differently when they switch to a regime without bright lines?

In examining $\mathrm{H} 2$, we limit our attention to the three regimes whose lease standards included the "transfer of risks and rewards" principle in the standard, to avoid the potential confound of the difference studied in H1. We use three comparisons to study H2: (a) a time-series analysis of IAS17 versus domestic GAAP, within Australia and the UK; (b) a difference-in-differences analysis of Australia and the UK versus Canada, pre- and post-2005; and (c) IAS17 versus domestic GAAP, in the year of transition for Australia, Canada and the UK. We explain the details of the tests in the Research Design section.

\subsection{H3 and H4: eliminating or omitting bright lines reduces transaction structuring}

In our final tests, we look for evidence of transaction structuring in operating leases by considering features that relate to bright lines, specifically the lease term and the proportion of contingent rentals, discussed in turn below. Standard setters express concern about these features.

The IASB considered whether the proposals might ... provide incentives to structure transactions to achieve desired accounting outcomes. Examples include ... reducing the length of lease terms and making lease payments variable, all in an attempt to recognise smaller lease liabilities (IASB 2013, paragraph BC366).

If the bright line at $75 \%$ of useful life causes firms, ceteris paribus, to write lease contracts with artificially short lease terms, then we should find shorter operating lease terms in regimes with this bright line test. We state this hypothesis in alternative form, as follows. 
H3: Firms in regimes with no bright-line criterion for the lease term have longer operating lease terms than firms in regimes with such a criterion.

The UK never had this bright line, so the switch to IAS17 represents no change on this criterion. Canada and the US, on the other hand, had this criterion in both 2003 and 2007, so they also represent no change between these dates, albeit within the opposite regime. Australia moved from having this criterion under domestic GAAP to not having it under IAS17. Due to data limitations explained in Section 3.3, we cannot compare pre-2005 UK to other countries on this dimension. We therefore examine whether Australian companies increased their lease terms more than their industry counterparts in the other countries between 2003 and 2007. We further examine whether Australian and UK companies under IAS17 have longer lease terms than peer firms in Canada and the US.

To study the present value criterion, we examine contingent rentals, which companies can use to reduce their minimum lease payments to stay below the $90 \%$ threshold and qualify for operating lease treatment. If, ceteris paribus, the bright line causes firms to write contracts with artificially high contingent rentals, then removing the bright line could reduce their use. The hypothesis in alternative form follows.

H4: Firms in regimes with no bright-line criterion for the present value of minimum lease payments will use fewer contingent rentals in their operating leases than firms in regimes with such a criterion.

To study H4, we compare Australian and UK companies' use of contingent rentals before versus after 2005. We also compare Australian and UK companies under IAS17 to industry peers in the US, who retained this bright line. As we explain in Section 3.3, Canadian firms generally lack the data to estimate contingent rentals, so we cannot include them in tests of $\mathrm{H} 4$.

\section{Research design and descriptive statistics}

\subsection{Design}

Our first hypothesis is inherently cross-country: it pits the US, where FAS13 does not allow professional judgment to override the bright-line criteria, against other countries that require this professional judgment. Our remaining three hypotheses use crosscountry as well as within-country tests. Given that context, we identify countries that are as similar as possible in other respects that might affect accounting choice. By worldwide standards, our four countries are relatively homogeneous. They share linguistic, cultural, and legal backgrounds, along with the Anglo-Saxon accounting model. ${ }^{17}$ Using the 2005 scores from Brown et al. (2014), our four countries on average

\footnotetext{
${ }^{17}$ See Mueller et al. (1997) and Nobes (2011).
} 
differ by 1 on quality of audit environment and by 0.5 on enforcement of accounting standards, as compared with average differences of 8.43 and 7.80 , respectively, among the other 47 sample countries. ${ }^{18}$ We believe it would be difficult to find four countries with less variation in the non-accounting traits likely to affect accounting choices.

Our chosen countries are also among the strongest enforcement regimes in the world, with the highest 2005 enforcement scores among the 51 sample countries in Brown et al. (2014). Choosing the world's strongest enforcement regimes should reduce the risk that preparers and auditors fail to heed standards.

Given that we hand-collect much of the data for this study, our design attempts to maximize statistical power from a necessarily limited sample. ${ }^{19}$ Statistical power is a function of several factors, including (a) the size of the effect, (b) the background variation in outcomes that may obscure the effect, and (c) the sample size. We seek to maximize the size of the effect by choosing industries with substantial leasing of economically significant assets, namely retail and transportation. ${ }^{20}$ Companies in these industries tend to lease assets (in retail, premises; in transportation, vehicles) that are fundamental to their operations. In preliminary analysis, we found that these two industries had reasonable numbers of companies with relatively large amounts of lease activity in all four countries. Ensuring adequate numbers of observations addresses (c), the sample size. Within these countries, industries, and years, we employ nearly the full population of firms with available data. Hence we can increase sample size only at peril of introducing new variation.

We attempt to minimize background variation, item (b) in the above list, by choosing otherwise similar countries, as discussed above, by performing our analysis withinindustry to keep operating traits as similar as possible, and by statistically controlling for covariates that might affect individual companies' lease accounting decisions. With our industry selection and within-industry analysis, we attempt to hold constant the economic role of the leased assets in the companies' operations, which we believe is consistent with the spirit of pre-2016 lease standards. Our cross-sectional tests rely on the maintained assumption that leased assets within an industry across countries are economically similar.

An alternative view is that contract terms, not the economic role of the asset, define the economic substance of the lease, so we should attempt to hold contract terms constant. Our transition-year test of $\mathrm{H} 2$ addresses this alternative. In this test, described in detail in Section 4.2, we use the opening balance sheet in the year of IFRS adoption, for which we have both domestic GAAP and IAS17 representations of the same contracts. $^{21}$

\footnotetext{
${ }^{18}$ These four countries are also relatively similar on law enforcement institutions (DeFond and Hung 2004) and accounting standards enforcement (Hope 2003). While accounting standards and enforcement are to some extent jointly determined, we seek to minimize the impact of enforcement by maximizing similarity across regimes.

${ }^{19}$ We hand-collect data because preliminary analysis showed that Compustat lease data were incomplete or inaccurate on key variables in some sample countries. Details of this analysis are available from the authors upon request.

${ }^{20}$ We are grateful to Kenneth French for making the Fama-French industry definitions freely available: http://mba.tuck.dartmouth.edu/pages/faculty/ken.french/Data_Library.

${ }^{21}$ We are grateful for a reviewer's suggestion that led to this approach.
} 
Table 1 Sample Selection, by Industry and Country

\begin{tabular}{|c|c|c|c|c|c|c|c|c|}
\hline & \multicolumn{4}{|l|}{ Retail } & \multicolumn{4}{|c|}{ Transportation } \\
\hline & Australia & Canada & UK & US & Australia & Canada & UK & US \\
\hline Firms with Compustat data in 2007 & 39 & 31 & 94 & 310 & 30 & 26 & 54 & 162 \\
\hline \multicolumn{9}{|l|}{ Less: } \\
\hline Firms lacking 2003 Compustat data & -12 & -9 & -36 & -91 & -9 & -11 & -20 & -49 \\
\hline $\begin{array}{l}\text { Firms reporting under non-domestic } \\
\text { GAAP }\end{array}$ & $\underline{0}$ & $\underline{-1}$ & $\underline{0}$ & -3 & $\underline{0}$ & $\underline{-2}$ & -1 & 0 \\
\hline $\begin{array}{l}\text { Sample for hand data collection from annual } \\
\text { reports }\end{array}$ & 27 & 21 & 58 & 216 & 21 & 13 & 33 & 113 \\
\hline \multicolumn{9}{|l|}{ Less: } \\
\hline Firms lacking one or both annual reports & -1 & 0 & -6 & -30 & 0 & -1 & -3 & -20 \\
\hline Firms lacking essential lease information & 0 & 0 & -3 & -2 & -2 & 0 & 0 & -2 \\
\hline $\begin{array}{l}\text { Subsidiaries of parent firms also included } \\
\text { in our sample }\end{array}$ & 0 & -1 & 0 & 0 & 0 & 0 & 0 & -3 \\
\hline Firms not adopting IFRS & 0 & $\mathrm{~N} / \mathrm{A}$ & -6 & N/A & 0 & $\mathrm{~N} / \mathrm{A}$ & 0 & N/A \\
\hline $\begin{array}{l}\text { Retail firms in SIC 5961, and } \\
\text { transportation firms not using } \\
\text { transportation equipment (e.g. airplanes, } \\
\text { trucks, ships) }\end{array}$ & $\underline{-3}$ & $\underline{0}$ & $\underline{-4}$ & $\underline{-20}$ & $\underline{-8}$ & $\underline{-6}$ & $\underline{-21}$ & $\underline{-23}$ \\
\hline Final sample - firms & 23 & 20 & 39 & 164 & 11 & 6 & 9 & 65 \\
\hline Final sample - firm-years & 46 & 40 & 78 & 328 & 22 & 12 & 18 & 130 \\
\hline
\end{tabular}

Table 1 presents our sample selection process. We classify firms as retail or transportation using the FamaFrench 48 mapping and Compustat SIC codes. We omit retail firms in SIC 5961 (catalog and mail-order houses), because the business model does not rely on sales premises, and likewise omit transportation firms (e.g. travel agencies) whose business models do not employ transportation equipment

\subsection{Sample}

Table 1 shows the sample selection stages for our main analyses, along with the data lost at each stage, by country and industry. We begin with companies listed in Compustat North America and Compustat Global for our four countries and two industries in 2007. Because most leases are long-term, information for a given firm changes little from year to year. We therefore choose to collect only one observation per firm before and one per firm after December 2005, the IFRS transition date for Australia and for LSE-listed companies in the UK. We choose 2003 for the pre-IFRS year because firms restated their opening (2004) balance sheets when they switched to IFRS; 2003 gives us the last year of the old regime. We choose 2007 for symmetry around the switch, and because a wider window increases the risk that structural changes, such as legal or tax changes, could confound inferences. ${ }^{22} \mathrm{Next}$, we eliminate (1) firms with Compustat Total Assets either missing or zero in 2003, (2) firms that did not use the country's domestic GAAP (e.g., Canadian firms reporting under US GAAP),

\footnotetext{
${ }^{22}$ A potential drawback of our narrow window is that firms do not have a long experience with IFRS in our post-IFRS period. We mitigate this concern with a supplemental analysis examining Australian and UK firms in 2010. Results from that analysis reinforce our main results.
} 
(3) firms missing annual reports or missing information in those annual reports, ${ }^{23}$ (4) firms that are subsidiaries of parent companies already in our sample, (5) UK and Australian firms that did not adopt IFRS in 2005, and (6) firms whose descriptions of the business, leased assets, or both do not fit our target profile of leased assets integral to operations. $^{24}$

For the transition-year analysis, we obtain annual reports for the year before and the year of transition to IFRS, for sample Australian and UK firms. For this analysis, we reapply the sample conditions to Canada in 2011, resulting in a slightly different Canadian sample from the one used in 2005 tests.

After hand-collecting lease data, we perform a number of checks to ensure data accuracy and investigate discrepancies against the original source: (1) we compare our hand-collected data to Compustat data (where available); (2) we flag observations where leased assets, capital lease commitments, or operating lease commitments exceed total assets; (3) we identify observations with unusually high capital lease use or no lease usage; and (4) within firms, we check for internal consistency in the footnote disclosure of future cash commitments.

\subsection{Measures}

The appendix summarizes our variable definitions. For our first two hypotheses, we measure capital lease use for each firm as the ratio of capital leases to total leases, and then average across firms in a given country-industry-year. To construct total leases, we first place operating and capital leases on a comparable basis by aggregating undiscounted operating lease commitments plus undiscounted capital lease commitments. ${ }^{25}$

The pre-IFRS UK did not require firms to report aggregate undiscounted lease commitments. Rather, UK disclosures included only the next year's commitments, grouped by lease expiry date. To place the UK data on a basis comparable to other sample countries' data, we assume that, in 2003, UK firms had a similar pattern of lease commitments to patterns observed in 2007, when their disclosure under IAS17 converged with that of other countries. In particular, we assume that next year's lease commitments represent the same percentage of total lease commitments in both 2003 and 2007 and estimate 2003 total lease commitments by grossing up the next year commitment. ${ }^{26}$

\footnotetext{
${ }^{23}$ We obtain annual reports for sample companies, either from company websites, or from the following sources: for Australia, from Annual Reports Online by Aspect Huntley via the National Library of Australia (we thank Joseph Cheng) or through Mergent On-line; for Canada, from the Canadian Securities Administrators' SEDAR site; for the UK, from Companies House or Mergent On-line; and for the US, from the Securities and Exchange Commission's EDGAR site.

${ }^{24}$ On this basis, we eliminated SIC 5961, catalog and mail-order houses, from retail, and several transportation companies that lack vehicles, for example, travel agencies, brokerage firms, and self-storage firms. Although this step further reduces an already small sample, it eliminates firms where the magnitude of the economic effect (issue (a) in our statistical power list) is likely to be small or non-existent.

${ }^{25}$ We considered two other candidate bases: (1) discounted lease commitments, calculated as the capitalized liability value of noncancellable operating leases using the method of Imhoff et al. (1991), plus the reported liability value of capital leases; and (2) annual lease payments, calculated as the annual operating rent expense, plus current-year cash payments under capital leases. We decided against (1) because it requires additional assumptions, and against (2) because operating rent expense is unavailable for Canada.

${ }^{26}$ Detailed analysis of the estimation needed to make the pre-IFRS UK disclosures comparable to those of other countries is available from the authors upon request.
} 
Many pre-IFRS UK companies and a small number of companies in other jurisdictions report only discounted, and not undiscounted, future capital lease commitments. ${ }^{27}$ In these cases, we use the ratio of undiscounted to discounted capital lease commitments for other companies in the same industry-country-year to gross up the discounted value.

We face similar data perils in measuring operating lease term and contingent rentals to test $\mathrm{H} 3$ and $\mathrm{H} 4$, about transaction structuring. Companies variously report the maximum lease term, a range of terms, a longest expiry date, or nothing at all about term. No sample company provides details to relate monetary amounts to periods beyond five years. We compute a weighted-average lease term, using the undiscounted cash flow amounts in each year as the weights and assuming that the lump-sum amount beyond five years expires in equal installments, equal to the amount in year five. When the firm reports a lump-sum cash flow for years two through five together, as is common in the UK and Australia, we assign equal monetary amounts to each year in the interval.

Few companies in any country disclose contingent rentals, so we rely on a proxy. ${ }^{28}$ We conjecture that the difference between the amount disclosed as one-year-ahead operating lease commitment in year $t-1$ and the actual operating lease expense in year $t$, comprises mainly contingent rents. Consequently, to estimate the contingent proportion of operating lease expense, we calculate one minus the ratio of prior year disclosed commitment to current year operating lease expense. A higher value represents more contingent rentals. We cannot measure this amount for Canadian companies because too few disclose operating lease expense.

Overall, our experience with the data confirms that seemingly small differences in disclosure requirements, or in companies' compliance with disclosure requirements, can have substantial effects on comparability across jurisdictions. For example, the fact that few sample Canadian companies report operating lease expense excludes Canada from our investigation of H4. Furthermore, few Australian companies provided the required disclosure on contingent rentals, and UK firms provided limited operating lease information under domestic GAAP. Financial analysts wishing to use lease disclosures to analyze leasing transactions across regimes would face similar impediments to these.

\subsection{Descriptive statistics}

Table 2 provides descriptive information about our sample companies, by country within industry. We state total assets and revenue in US dollars to allow comparison across countries. In both industries, US firms are largest in terms of both assets and revenue, while Australian firms are generally smallest. We use ratio measures in our univariate tests to mitigate problems stemming from differences in firm size across countries and include size as a control variable in multivariate tests.

Australian retail companies and UK transportation companies exhibit the highest return on equity in their respective industries, at 18 and 16\%. In all countries, asset

\footnotetext{
${ }^{27}$ Outside of the UK, 13 companies reported only discounted future capital lease commitments: one Australian transportation, three Canadian retail, six US retail, and three US transportation companies.

${ }^{28}$ Australia requires that companies separately disclose both current year operating lease minimum payments and contingent rentals (see AASB1008 paragraph 11.1(b)); however, no other sample country requires the same disclosure, and only $17.6 \%$ of sample Australian companies list contingent rentals, despite the requirement. As a result, we use our constructed proxy for Australia as well. For the 12 observations with reported values for contingent rentals, our constructed measure has a 54\% (39\%) Pearson (Spearman) correlation with the reported values.
} 
Table 2 Descriptive Information about Sample Firms

\begin{tabular}{|c|c|c|c|c|c|c|c|c|}
\hline & \multicolumn{4}{|l|}{ Retail } & \multicolumn{4}{|c|}{ Transportation } \\
\hline & Australia & Canada & UK & US & Australia & Canada & UK & US \\
\hline \multicolumn{9}{|l|}{ Total assets (US\$millions) } \\
\hline Mean & 695.3 & $2,208.4$ & $3,792.1$ & $3,959.3$ & $1,939.9$ & $2,512.0$ & $4,910.0$ & $5,427.4$ \\
\hline Median & 104.0 & 574.0 & 427.3 & 864.5 & 63.6 & 863.5 & $2,588.3$ & 803.3 \\
\hline \multicolumn{9}{|c|}{ Total revenue (US\$millions) } \\
\hline Mean & $1,794.9$ & $4,074.7$ & $5,900.7$ & $8,181.2$ & $1,550.6$ & $1,540.0$ & $4,434.9$ & $3,937.8$ \\
\hline Median & 268.5 & 948.9 & 991.7 & $1,544.3$ & 118.1 & $1,142.0$ & $3,736.1$ & 713.1 \\
\hline \multicolumn{9}{|l|}{ Net income $\div$ Equity } \\
\hline Mean & 0.26 & 0.11 & 0.22 & 0.05 & 0.13 & 0.12 & 0.32 & -0.27 \\
\hline Median & 0.18 & 0.13 & 0.13 & 0.11 & 0.11 & 0.14 & 0.16 & 0.10 \\
\hline \multicolumn{9}{|c|}{ Net income $\div$ Total revenue } \\
\hline Mean & 0.046 & -0.046 & 0.031 & -0.001 & 0.049 & 0.068 & 0.040 & 0.031 \\
\hline Median & 0.036 & 0.033 & 0.024 & 0.022 & 0.042 & 0.061 & 0.035 & 0.034 \\
\hline \multicolumn{9}{|l|}{ Total revenue $\div$ Total assets } \\
\hline Mean & 2.3 & 2.0 & 2.0 & 2.1 & 1.4 & 1.3 & 1.4 & 2.6 \\
\hline Median & 2.6 & 1.9 & 1.9 & 2.0 & 1.1 & 1.1 & 1.2 & 1.0 \\
\hline \multicolumn{9}{|l|}{ Total assets $\div$ Equity } \\
\hline Mean & 2.82 & 2.04 & 4.32 & 2.73 & 2.51 & 2.39 & 4.91 & 9.44 \\
\hline Median & 2.34 & 1.98 & 2.22 & 2.06 & 2.32 & 2.50 & 3.71 & 2.33 \\
\hline \multicolumn{9}{|c|}{ Total borrowing $\div$ Total assets } \\
\hline Mean & 0.25 & 0.18 & 0.20 & 0.24 & 0.29 & 0.26 & 0.28 & 0.31 \\
\hline Median & 0.25 & 0.22 & 0.15 & 0.18 & 0.28 & 0.31 & 0.28 & 0.29 \\
\hline \multicolumn{9}{|c|}{ Net property, plant $\&$ equipment $\div$ Total assets } \\
\hline Mean & 0.25 & 0.33 & 0.36 & 0.32 & 0.55 & 0.54 & 0.48 & 0.56 \\
\hline Median & 0.21 & 0.33 & 0.30 & 0.30 & 0.59 & 0.60 & 0.43 & 0.61 \\
\hline \multicolumn{9}{|c|}{ Total lease commitment $\div$ Total assets } \\
\hline Mean & 0.69 & 0.48 & 1.43 & 0.65 & 0.36 & 0.23 & 1.18 & 0.60 \\
\hline Median & 0.45 & 0.51 & 1.11 & 0.52 & 0.31 & 0.15 & 0.81 & 0.17 \\
\hline \multicolumn{9}{|l|}{ Auditor } \\
\hline Big 4 percentage & 0.67 & 0.85 & 0.82 & 0.85 & 0.77 & 1.00 & 1.00 & 0.91 \\
\hline Number of observations & 46 & 40 & 78 & 328 & 22 & 12 & 18 & 130 \\
\hline
\end{tabular}

Table 2 reports the mean and median firm size, operating characteristics, DuPont ratios, leverage, PPE and lease usage, and the proportion of firms in the country with a Big 4 auditor for our sample firm-years. Data are from Compustat, except lease commitments and auditor, which we hand-collect from annual reports. We convert other currencies to US dollars using the spot rate on the balance sheet date for balance sheet amounts, and the average annual rate for income statement amounts. For two ratios, net income $\div$ equity and total assets $\div$ equity, we exclude observations with negative equity values

turnover is higher in retail (median 1.9 to 2.6 times) than in transportation (median 1.0 to 1.2 times). Some large losses evidently influence the mean return on equity (negative in US transportation) and profit margin (negative in Canadian and US retail). The medians of both these profitability measures, however, are positive in all sector-countries.

Median leverage, excluding leases (total borrowing $\div$ total assets), ranges from 15 to $31 \%$ across sector-countries. Transportation firms employ more property, plant and equipment as a percentage of total assets, ranging from 43 to $61 \%$ versus 21 to $33 \%$ for 
retail firms. For descriptive purposes only, we approximate leased assets as the total undiscounted future payments on operating plus capital leases, scaled by total assets. By this measure, retail firms use more leases than transportation firms in all countries, with medians ranging from $45 \%$ in Australia to $111 \%$ in the UK, while in transportation, these figures range from $15 \%$ in Canada to $81 \%$ in the UK.

Table 3 provides the proportions of firms that report leases in each countryindustry-year, separately for operating and capital leases. Panel A of Table 3 shows substantial variation in the proportion of firms reporting any capital leases, ranging from $28.2 \%$ in UK retail in 2003 to $100 \%$ in UK transportation in 2007. In contrast, Panel B shows that between 83.3 and $100 \%$ of the same companies use operating leases. All of the Panel B proportions are statistically indistinguishable from $100 \%$. Broadly speaking, companies in these industries are lessees, confirming our reason for focusing on these industries. We see wide variation across regimes and industries in the proportion of firms using capital leases, though little variation in the proportion using operating leases.

From the data in Panel A, we make several observations. The US does not emerge as an outlier in the proportion of firms avoiding capital leases, as we would expect if professional judgement promoted capital lease use. Averaged across years, the lowest proportion of firms recording any capital leases appears in the UK for retail (44.9\%) and in Canada for transportation (50.0\%). Australia reports the highest mean proportions in both industries. The UK experiences a surge in the proportion of firms using capital leases after its switch to IFRS, with retail increasing from 28.2 to $61.5 \%$ and transportation increasing from 56.0 to $100 \%$. Australia, however, experiences a decline in retail firms using capital leases after IFRS adoption, from 65.2 to $56.5 \%$, with transportation unchanged.

Table 3 Proportion of Firms Using Capital and Operating Leases, by Country, Industry, and Period

\begin{tabular}{|c|c|c|c|c|c|c|c|c|}
\hline \multirow[t]{2}{*}{ Industry } & \multicolumn{4}{|l|}{ Retail } & \multicolumn{4}{|c|}{ Transportation } \\
\hline & 2003 & 2007 & Mean & $\mathrm{N}$ & 2003 & 2007 & Mean & $\mathrm{N}$ \\
\hline \multicolumn{9}{|c|}{ Panel A: Percentage of firms reporting capital leases, by country-industry-year } \\
\hline Australia & $65.2 \%$ & $56.5 \%$ & $60.9 \%$ & 23 & $81.8 \%$ & $81.8 \%$ & $81.8 \%$ & 11 \\
\hline Canada & $55.0 \%$ & $60.0 \%$ & $57.5 \%$ & 20 & $50.0 \%$ & $50.0 \%$ & $50.0 \%$ & 6 \\
\hline UK & $28.2 \%$ & $61.5 \%$ & $44.9 \%$ & 39 & $56.0 \%$ & $100.0 \%$ & $78.0 \%$ & 9 \\
\hline US & $44.5 \%$ & $49.4 \%$ & $47.0 \%$ & 164 & $49.2 \%$ & $52.3 \%$ & $50.8 \%$ & 65 \\
\hline
\end{tabular}

Panel B: Percentage of firms reporting operating leases, by country-industry-year

\begin{tabular}{lrrrrrrrr} 
Australia & $100.0 \%$ & $100.0 \%$ & $100.0 \%$ & 23 & $100.0 \%$ & $100.0 \%$ & $100.0 \%$ & 11 \\
Canada & $100.0 \%$ & $100.0 \%$ & $100.0 \%$ & 20 & $83.3 \%$ & $83.3 \%$ & $83.3 \%$ & 6 \\
UK & $100.0 \%$ & $100.0 \%$ & $100.0 \%$ & 39 & $100.0 \%$ & $100.0 \%$ & $100.0 \%$ & 9 \\
US & $100.0 \%$ & $99.4 \%$ & $99.7 \%$ & 164 & $92.3 \%$ & $95.4 \%$ & $93.9 \%$ & 65 \\
\hline
\end{tabular}

Table 3 reports the incidence of capital and operating lease use across sample countries, industries and periods. In Panel A, we report the percentage of companies that record any capital leases by country, industry, and period. In Panel B, we report the percentage of companies that disclose any operating lease commitments by country, industry and period 


\section{Results of hypotheses tests}

\subsection{Tests of H1: firms use more capital leases when the standard emphasizes the principle}

Our first hypothesis compares the US to the other three regimes. As we described in Section 3.3, we measure capital lease use as the average ratio of capital lease to total lease commitments, across companies that use leases within a country-industry. ${ }^{29}$ Because H1 is a cross-sectional hypothesis, we use the average of 2003 and 2007 measurements for each country in these tests. We obtain similar inferences if we separate 2003 and 2007.

Table 4 reports test results for H1. Panel A reports capital lease use by country and industry, while Panel B reports $p$-values for two-tailed tests of H1, using the normal approximation to the binomial distribution. We discuss two-tailed $p$ values of $10 \%$ or lower as significant. Panel $\mathrm{C}$ shows the results of estimating OLS regressions of capital lease use, including firm-specific control variables that could plausibly affect a firm's willingness to capitalize leases, while Panel D reports the $p$-values of tests of $\mathrm{H} 1$, similar to Panel B.

If a lease standard that explicitly states the broad principle promotes capital lease use, we would expect firms in Australia, Canada, and the UK to use more capital leases than their industry peers in the US. Table 4 Panel A shows that, in transportation, the US indeed reports the lowest average capital lease use, supporting H1, and its difference from Australia is statistically significant. In contrast, US retail firms report the second highest capital lease use, contrary to $\mathrm{H} 1$, with significantly higher lease use than the UK. 30

The impetus behind the confirming results for Australian firms is not sample size but a very large effect size: Australian firms use dramatically more capital leases than their peers in other countries. Untabulated tests show that Australian firms use significantly more capital leases than firms in the UK in both industries and significantly more than Canadian firms in retail. All three of these countries require professionals to judge whether the risks and rewards have transferred. Hence we cannot conclude that the Australia-US difference stems from this feature of accounting standards. Overall, rather than showing the US as an outlier in avoiding capital leases, these tests show Australia as an outlier in embracing them. We return to this point after discussing our regression tests.

\footnotetext{
${ }^{29}$ Omitting non-lessee companies reduces our sample by one US retail firm in 2007, one Canadian transportation firm in each of 2003 and 2007, and four US transportation firms in 2003 and three in 2007.

${ }^{30}$ Because our samples are small in some industry-countries, we assess the effect of sample size on insignificant differences. Increasing sample size affects only the standard error, not the mean of the test, as long as observations are drawn from the same distribution. In retail, Canada's insignificant difference, like the UK's significant difference, is opposite the H1 prediction. In this case, no increase in sample size alone could support H1. In transportation, the direction supports $\mathrm{H} 1$ in all cases. A sample of 25 Canadian companies drawn from the same distribution would yield a $p$-value below 10\%. For the UK, even a sample of 62 companies (the US sample size) would not yield significance at the $10 \%$ level.
} 
Table 4 Capital Lease Use, by Country, Industry, and Period, and Tests of H1

Panel A: Capital lease use for firms using leases, by country-industry, for 2003, 2007, and mean across periods

\begin{tabular}{lllllllll} 
Industry & Retail & \multicolumn{7}{c}{ Transportation } \\
Country \Year & $\mathbf{2 0 0 3}$ & $\mathbf{2 0 0 7}$ & Mean & $\mathbf{N}$ & $\mathbf{2 0 0 3}$ & $\mathbf{2 0 0 7}$ & Mean & N \\
Australia & $12.2 \%$ & $7.7 \%$ & $9.9 \%$ & 23 & $40.1 \%$ & $46.2 \%$ & $43.1 \%$ & 11 \\
Canada & $1.0 \%$ & $1.2 \%$ & $1.1 \%$ & 20 & $18.0 \%$ & $12.5 \%$ & $15.2 \%$ & 5 \\
UK & $0.7 \%$ & $1.1 \%$ & $0.9 \%$ & 39 & $10.1 \%$ & $12.5 \%$ & $11.3 \%$ & 9 \\
US & $2.7 \%$ & $3.8 \%$ & $3.3 \%$ & $164 / 163$ & $8.5 \%$ & $6.6 \%$ & $7.5 \%$ & $61 / 62$
\end{tabular}

Panel B: Univariate tests of H1: US firms use fewer capital leases than firms in other regimes ( $p$-values in parentheses)

$\begin{array}{llcc} & \text { Prediction } & \text { Retail } & \text { Transportation } \\ \text { AUS - US } & (+) & 6.7 \% & 35.6 \% \\ & & \mathbf{( 0 . 0 1 )} & (<\mathbf{0 . 0 0 0 1 )} \\ \text { CDA - US } & (+) & -2.2 \% & 7.7 \% \\ & & (0.27) & (0.38) \\ \text { UK - US } & (+) & -2.4 \% & 3.7 \% \\ & & \mathbf{( 0 . 1 0 )} & (0.58)\end{array}$

Panel C: OLS regression analysis of capital lease use (t-statistics in parentheses)

\begin{tabular}{|c|c|c|c|}
\hline \multirow[t]{2}{*}{ Variable } & \multirow[t]{2}{*}{ Coefficient } & \multicolumn{2}{|c|}{ Capital lease use } \\
\hline & & Retail & Transportation \\
\hline AUS & $\alpha_{A U S}$ & $\begin{array}{l}0.10 \\
(1.71)\end{array}$ & $\begin{array}{c}0.29 \\
(\mathbf{2 . 6 7 )}\end{array}$ \\
\hline CDA & $\alpha_{C D A}$ & $\begin{array}{c}-0.01 \\
(-0.26)\end{array}$ & $\begin{array}{c}0.02 \\
(0.18)\end{array}$ \\
\hline UK & $\alpha_{U K}$ & $\begin{array}{c}-0.01 \\
(-0.22)\end{array}$ & $\begin{array}{c}-0.02 \\
(-0.19)\end{array}$ \\
\hline US & $\alpha_{U S}$ & $\begin{array}{c}0.02 \\
(0.63)\end{array}$ & $\begin{array}{c}-0.08 \\
(-0.86)\end{array}$ \\
\hline Size & $\beta_{1}$ & $\begin{array}{c}0.001 \\
(0.18)\end{array}$ & $\begin{array}{c}0.01 \\
(0.51)\end{array}$ \\
\hline Lev & $\beta_{2}$ & $\begin{array}{c}-0.02 \\
(-0.64)\end{array}$ & $\begin{array}{c}0.09 \\
(1.15)\end{array}$ \\
\hline Profit & $\beta_{3}$ & $\begin{array}{c}-0.21 \\
(-\mathbf{3 . 0 8})\end{array}$ & $\begin{array}{c}0.18 \\
(0.95)\end{array}$ \\
\hline Var & $\beta_{4}$ & $\begin{array}{c}-0.35 \\
(-3.16)\end{array}$ & $\begin{array}{c}0.09 \\
(0.91)\end{array}$ \\
\hline PPE & $\beta_{5}$ & $\begin{array}{c}0.11 \\
(\mathbf{1 . 9 7 )}\end{array}$ & $\begin{array}{c}0.25 \\
(\mathbf{2 . 1 6})\end{array}$ \\
\hline Growth & $\beta_{6}$ & $\begin{array}{c}0.08 \\
(\mathbf{1 . 8 4})\end{array}$ & $\begin{array}{c}-0.22 \\
(\mathbf{- 1 . 9 4 )}\end{array}$ \\
\hline Big4 & $\beta_{7}$ & $\begin{array}{c}0.01 \\
(0.62)\end{array}$ & $\begin{array}{c}-0.06 \\
(-0.60)\end{array}$ \\
\hline $\mathrm{N}$ & & 246 & 88 \\
\hline $\operatorname{adj} . R^{2}$ & & 0.236 & 0.421 \\
\hline
\end{tabular}


Table 4 (continued)

Panel D: Panel regression tests of H1: US firms use fewer capital leases than firms in other regimes (p-values in parentheses)

$\begin{array}{llll} & \text { Prediction } & \text { Retail } & \text { Transportation } \\ \text { AUS - US } & (+) & 0.08 & 0.37 \\ & & \mathbf{( 0 . 0 3 5 )} & \mathbf{( 0 . 0 0 1 )} \\ \text { CDA - US } & (+) & -0.03 & 0.10 \\ & & \mathbf{( 0 . 0 0 5 )} & (0.214) \\ \text { UK - US } & (+) & -0.01 & 0.06 \\ & & \mathbf{( 0 . 0 1 4 )} & (0.374)\end{array}$

Table 4 presents our tests of H1: Firms in regimes where standards emphasize an overriding principle report more capital leases than US firms. See Appendix for variable definitions. These tests include all sample firm-years with any leasing activity. Panel A tabulates average capital lease use, while Panel B tabulates the associated t-tests of H1. Panel C presents OLS regression results with capital lease use, averaged across 2003 and 2007 measurements for each firm, as the dependent variable. Heteroskedasticity-consistent t-statistics in parentheses test whether the coefficient equals zero. Panel D tabulates the associated tests of H1. The model for Panels $\mathrm{C}$ and D is (1): CapLease $_{i}=\alpha_{c}+\beta_{1}$ Size $_{i}+\beta_{2}$ Lev $_{i}+\beta_{3}$ Profit $_{i}+\beta_{4}$ Var $_{i}+\beta_{5}$ PPE $_{i}+\beta_{6}$ Growth $_{i}+\beta_{7}$ Big $_{i}+\varepsilon_{i}$.

All $p$-values are two-tailed. In Panels $\mathrm{B}, \mathrm{C}$, and $\mathrm{D}$, bold indicates a $p$-value below 0.10 , while bold italics indicate both a $p$-value below 0.10 and direction consistent with the stated alternative hypothesis

Table 4 Panel $\mathrm{C}$ reports the results of estimating regressions that control for firmspecific factors that could influence the operating versus capital lease decision, which we specify as:

$$
\begin{aligned}
\text { CapLease }_{i}= & \alpha_{c}+\beta_{1} \text { Size }_{i}+\beta_{2} \text { Lev }_{i}+\beta_{3} \text { Profit }_{i}+\beta_{4} \text { Var }_{i}+\beta_{5} \text { PPE }_{i} \\
& +\beta_{6} \text { Growth }_{i}+\beta_{7} \text { Big }_{i}+\varepsilon_{i},
\end{aligned}
$$

where $i$ indexes companies, and $c$ indexes countries. The dependent variable, CapLease, is the firm-by-firm measure summarized in the "Mean" column in Panel A. We estimate Eq. (1) using ordinary least squares (OLS), omitting the overall intercept to estimate four country-specific intercepts, $\alpha_{c}$, which we use to test $\mathrm{H} 1$.

where $i$ indexes companies, and $c$ indexes countries. The dependent variable, CapLease, is the firm-by-firm measure summarized in the "Mean" column in Panel A. We estimate Eq. (1) using ordinary least squares (OLS), omitting the overall intercept to estimate four country-specific intercepts, $\alpha_{c}$, which we use to test H1.

Pooling across countries in Eq. (1) increases degrees of freedom, and the addition of control variables should reduce the unexplained variation (and hence standard errors), creating the potential for more significant relations. We include Size, the natural log of total assets at the beginning of the year, because larger firms may operate differently from small ones. To control for the possibility that companies with higher nonlease leverage may avoid capital lease treatment, we include $L e v$, the ratio of long-term borrowing to total assets at the beginning of the year. More profitable firms and those with less variable profit streams, may be better able to support the appearance of higher leverage created by capital leases. To control for this, we include Profit, the average of current and 
the past four years' earnings before interest and taxes, scaled by total assets, and the standard deviation of the same series, Var. We include PPE, the ratio of nonleased fixed assets to total assets at the beginning of the year, to control for the company's fixed asset intensity, and Growth, the percentage change in total assets from last year to the current year, because the differential effects of capital leases on the income statement relate to growth. Finally, we include Big4, an indicator variable that takes the value 1 if the company used a Big 4 auditor, to capture the influence of auditor on lease classification.

The regression analysis in Panel $\mathrm{C}$ and statistical tests in Panel D confirm the conclusions from the univariate tests in Panel B. US firms use proportionately fewer capital leases than Australian firms in both industries. In contrast, US firms record more capital leases than UK and Canadian firms in retail but demonstrate no statistical differences with either country in transportation. Our evidence overall does not support H1, that emphasizing the overriding principle within the standard promotes the use of capital leases. Controlling for firm-specific motives for preferring operating lease treatment does not alter this conclusion. As noted above, rather than showing the US as unique in avoiding capital leases, our results show Australia to be an outlier in using them.

Upon further investigation, we find that Australian firms' extensive use of hire purchase contracts accounts for much of the difference between Australia and the other countries. ${ }^{31}$ These contracts transfer ownership at the end of the lease and therefore must be capitalized under any of the regimes we study. In Canada and the US, companies tend to use installment purchases, rather than hire purchase contracts, to achieve similar cash flow consequences, and would record an owned asset, not a lease. UK companies also use hire purchase contracts but tend not to separate them from other capital leases. We therefore cannot know the extent of hire purchases in the UK.

\subsection{Tests of H2: eliminating bright lines promotes capital lease treatment}

In Tables 5 and 6, we evaluate $\mathrm{H} 2$, whether removing bright lines promotes capital lease use. For this analysis, to avoid any confound from the principle/rule issue that we study under H1, we restrict attention to Australia, Canada, and the UK, the three countries that emphasize the principle of transferring risks and rewards. If removing bright lines matters, then we expect firms in Australia and the UK to increase their use of capital leases when they switch from domestic standards to IAS17. We further expect these increases to exceed any contemporaneous changes in Canada between 2003 and 2007. In the IFRS transition year, we expect firms to report more of their existing lease contracts as capital leases under IAS17 than under domestic GAAP.

Table 5 Panel A repeats the data from Table 4 on capital lease use for Australia, Canada, and the UK. Panel B presents within-regime time-series tests. Panel C reports difference-in-difference comparisons. Panel D reports a regression analysis and Panel E reports statistical tests of $\mathrm{H} 2$ based on the regression. ${ }^{32}$

\footnotetext{
${ }^{31}$ Excluding hire purchase contracts causes Australian firms' average capital lease use to fall from 9.9 to $7.8 \%$ in retail and from 43.1 to $14.4 \%$ in transportation.

${ }^{32}$ We also perform Wilcoxon rank-sum tests on the differences between countries, within industry and year. We find fewer statistically significant differences in the rank tests and no results that contradict what we report based on t-tests.
} 
Table 5 Capital Lease Use, by Country, Industry, and Period, and Tests of H2

\begin{tabular}{llllllr}
\hline \multicolumn{2}{l}{$\begin{array}{l}\text { Panel A: Capital lease use for firms using leases, by country-industry-year } \\
\text { Industry }\end{array}$} & Retail & & \multicolumn{4}{c}{ Transportation } \\
Country $\backslash$ Year & $\mathbf{2 0 0 3}$ & $\mathbf{2 0 0 7}$ & $\mathbf{N}$ & $\mathbf{2 0 0 3}$ & $\mathbf{2 0 0 7}$ & N \\
Australia & $12.2 \%$ & $7.7 \%$ & 23 & $40.1 \%$ & $46.2 \%$ & 11 \\
Canada & $1.0 \%$ & $1.2 \%$ & 20 & $18.0 \%$ & $12.5 \%$ & 5 \\
UK & $0.7 \%$ & $1.1 \%$ & 39 & $10.1 \%$ & $12.5 \%$ & 9
\end{tabular}

Panel B: Time-series tests of H2: Australian and UK firms increase capital lease use after IFRS, relative to pre-IFRS ( $p$-values in parentheses)

$\begin{array}{lllc} & \text { Prediction } & \text { Retail } & \text { Transportation } \\ \text { AUS-2007 - AUS-2003 } & (+) & -4.5 \% & 6.1 \% \\ & & (0.47) & (0.69) \\ \text { UK-2007 - UK-2003 } & (+) & 0.4 \% & 2.4 \% \\ & & (0.29) & (0.82)\end{array}$

Panel C: Difference-in-differences tests of H2: Australian and UK firms increase capital lease use more than Canadian firms between 2003 and 2007 ( $p$-values in parentheses)

\begin{tabular}{lllll}
$\Delta$ AUS - $\triangle$ CDA & & Prediction & Retail & Transpor \\
& 2007 & $(+)$ & $-4.7 \%$ & $11.6 \%$ \\
$\Delta \mathrm{UKK}-\Delta \mathrm{CDA}$ & \multirow{2}{*}{2007} & $(+)$ & $(0.13)$ & $(0.31)$ \\
& & & $0.3 \%$ & $7.9 \%$ \\
& & & $(0.64)$ & $(0.20)$
\end{tabular}

Panel D: OLS regression analysis of capital lease use using Model (2) (t-statistics in parentheses)

Variable

Coefficient

AUS

$\alpha_{A U S}$

CDA

$\alpha_{C D A}$

UK

$\alpha_{U K}$

AUS*Post $\quad \delta_{A U S}^{\text {post }}$

CDA*Post $\quad \delta_{C D A}^{\text {post }}$

UK*Post $\quad \delta_{U K}^{\text {post }}$

Size $\quad \beta_{1}$

Lev $\quad \beta_{2}$

Profit

Var

$\beta_{4}$

Capital lease use

Retail

0.11

(1.17)

0.05

(1.07)

0.05

(1.07)

$-0.01$

$(-0.13)$

0.01

(1.04)

0.004

(0.39)

$-0.01$

(-1.59)

0.04

(1.46)

$-0.21$

(-1.92)

0.12
Transportation

0.05

(0.18)

$-0.01$

$(-0.03)$

$-0.16$

$(-0.54)$

0.13

(0.87)

$-0.14$

$(-0.66)$

0.10

(0.86)

$-0.03$

(-1.01)

0.73

(2.69)

$-0.09$

(-0.10)

0.81 
Table 5 (continued)

\begin{tabular}{|c|c|c|c|c|c|}
\hline \multirow{3}{*}{ PPE } & & & & $(0.38)$ & $(0.58)$ \\
\hline & \multirow{2}{*}{\multicolumn{3}{|c|}{$\beta_{5}$}} & 0.04 & 0.40 \\
\hline & & & & $(1.38)$ & $(1.64)$ \\
\hline \multirow[t]{2}{*}{ Growth } & \multirow{2}{*}{\multicolumn{3}{|c|}{$\beta_{6}$}} & 0.11 & -0.20 \\
\hline & & & & (1.93) & $(-0.80)$ \\
\hline \multirow[t]{2}{*}{ Big4 } & \multirow{2}{*}{\multicolumn{3}{|c|}{$\beta_{7}$}} & -0.01 & 0.05 \\
\hline & & & & $(-0.24)$ & $(0.26)$ \\
\hline \multicolumn{4}{|l|}{$\mathrm{N}$} & 151 & 47 \\
\hline \multicolumn{4}{|l|}{ adj. R2 } & 0.177 & 0.581 \\
\hline \multicolumn{6}{|c|}{$\begin{array}{l}\text { Panel E: Panel regression tests of } \mathrm{H} 2 \text { : Aus } \\
\text { relative to pre-IFRS, or more than Can } \\
\text { Panel D ( } p \text {-values in parentheses) }\end{array}$} \\
\hline & & Prediction & Retail & Trans! & \\
\hline \multirow{2}{*}{\multicolumn{2}{|c|}{ AUS-2007 - AUS-2003 }} & $(+)$ & -0.01 & 0.13 & \\
\hline & & & $(0.39)$ & $(0.69)$ & \\
\hline \multirow{3}{*}{\multicolumn{2}{|c|}{ UK-2007 - UK-2003 }} & $(+)$ & 0.004 & 0.10 & \\
\hline & & & $(0.69)$ & $(0.40)$ & \\
\hline & & Prediction & Retail & Trans! & \\
\hline \multirow[t]{2}{*}{$\Delta \mathrm{AUS}-\Delta \mathrm{CDA}$} & 2007 & $(+)$ & -0.02 & 0.26 & \\
\hline & & & $(0.75)$ & $(0.27)$ & \\
\hline \multirow[t]{2}{*}{$\Delta \mathrm{UK}-\Delta \mathrm{CDA}$} & 2007 & $(+)$ & -0.01 & 0.24 & \\
\hline & & & $(0.57)$ & $(0.33)$ & \\
\hline
\end{tabular}

Table 5 presents our time-series and difference-in-differences tests of H2: firms report more capital leases when the standard omits bright lines. See Appendix for variable definitions. These tests include all sample firm-years with any leasing activity. We exclude the US from our tests of $\mathrm{H} 2$ because the US standard is not written as an overriding principle. Panel A tabulates average capital lease use. Panel B tabulates the univariate time-series tests of differences in capital lease use between 2003 and 2007, for Australia and the UK. Panel C reports the univariate difference-in-differences tests; specifically, we calculate the difference between the changes from 2003 to 2007 for the test country and Canada. Panel D presents OLS regression results using capital lease use as the dependent variable in Model (2): CapLease $_{i t}=\alpha_{c}+\delta_{c}^{\text {post }}+\sum_{j=1}^{7} \beta_{j}$ Control $_{j i t}+\eta_{i t}$. Heteroskedasticity-consistent t-statistics in parentheses test whether the coefficient equals zero. Panel E tabulates the time-series and difference-in-differences tests of $\mathrm{H} 2$ based on the regression results in Panel D. For the time-series tests, we test whether $\delta_{A U S}^{\text {post }}$ and $\delta_{U K}^{\text {post }}$ differ significantly from 0 . For the difference-indifferences tests, we test $\delta_{\text {Test }}^{\text {post }}-\delta_{C D A}^{\text {post }}=0$, for Test $\in\{$ AUS, UK $\}$. All $p$-values are two-tailed. In Panels B, through $\mathrm{E}$, bold indicates a $p$-value below 0.10 , while bold italics indicate both a $p$-value below 0.10 and direction consistent with the stated alternative hypothesis

The time-series comparisons between 2003 and 2007 for Australia and the UK in Table 5 Panel B show no statistically significant changes. Capital lease use for Australian retail firms fell from 12.2 to $7.7 \%$ despite the removal of bright lines. In contrast, the UK shows increases in capital lease use in both industries, although its post-IFRS rate is the lowest among the three countries 


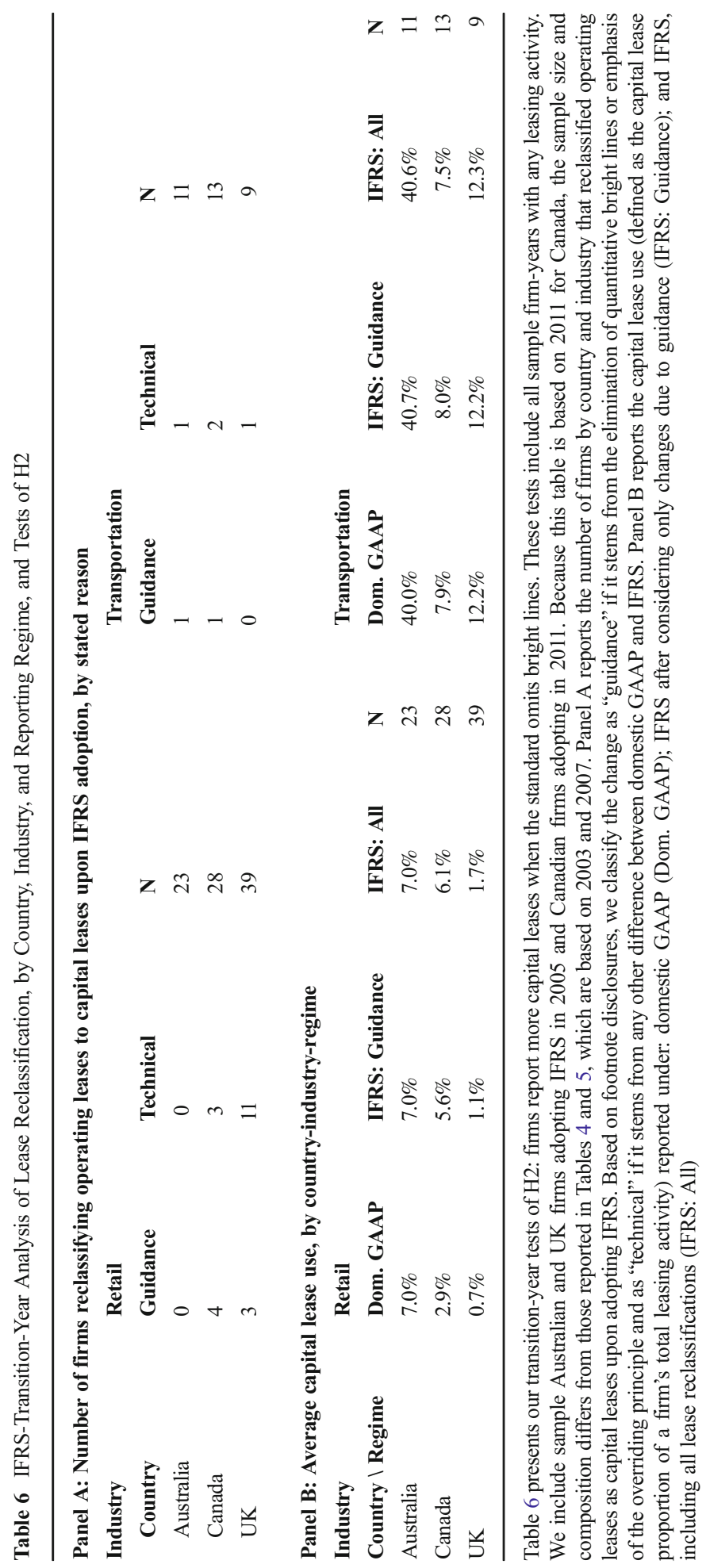


in retail and is tied with Canada in transportation. ${ }^{33} \mathrm{~A}$ potential reason for the lack of significance in these tests is that companies have not accumulated enough new leases by 2007 for changes to be noticeable. In untabulated analysis, we repeat these tests using Australian and UK lease data in 2010, five years after IFRS adoption. ${ }^{34}$ Even over this longer interval, we find no significant change in capital lease use for either country, in either industry. Overall, we no evidence in time-series tests to support that removing bright lines had a noticeable effect on lease capitalization.

Table 5 Panel $\mathrm{C}$ uses Canada as a control to provide difference-in-differences tests around the date when Australia and the UK adopted IFRS. This addresses the possibility that industry trends during the period might have affected firms' decisions about lease treatment, independent of IFRS adoption. Referring to Panel A, we see that Canadian firms' use of capital leases increased slightly in retail but decreased in transportation. None of the difference-in-difference tests reaches statistical significance at $10 \%$. Furthermore, the Australia-Canada comparison in the retail sector, at $p=13 \%$, is in the direction that refutes $\mathrm{H} 2 .{ }^{35}$ Overall, we find no evidence to support $\mathrm{H} 2$ from the difference-in-differences tests.

In addition to examining pair-wise univariate differences between regimes, in Panel $\mathrm{D}$ of Table 5 we estimate the following regression model using OLS:

$$
\text { CapLease }_{i t}=\alpha_{c}+\delta_{c}^{\text {post }}+\sum_{j=1}^{7} \beta_{j} \text { Control }_{j i t}+\eta_{i t},
$$

where $i$ indexes companies, $t \in\{2003,2007\}$ indexes time, $c \in\{$ AUS, CDA, UK $\}$ indexes countries, and $j$ indexes the control variables we introduced for Eq. (1): size, leverage, profitability, variance of profit, fixed asset intensity, asset growth, and Big 4 auditor. We augment Eq. (1) by including country-specific intercept shifts for the postIFRS period $\left(\delta_{c}^{\text {post }}\right)$. For the time-series tests of $\mathrm{H} 2$, the test variables are the intercept shifts, $\delta_{U K}^{\text {post }}$ and $\delta_{A U S}^{\text {post }}$, which measure the change pre- versus post-IFRS in the two countries that adopted IFRS. For the difference-in-differences tests, we compare the intercept shifts for an IFRS-adopting country versus for Canada, for example: $\delta_{U K}^{\text {post }}$ versus $\delta_{C D A}^{\text {post }}$.

Table 5 Panel D displays the results from estimating Eq. (2), while Panel E reports statistical tests for $\mathrm{H} 2$, comparable to the univariate tests in Panels B and C. These tests differ in details but confirm our overall conclusion from the univariate

\footnotetext{
${ }_{33}$ As before, we assess the effect of limited sample sizes on insignificant but directionally correct differences. Because capital lease use decreased post-IFRS for Australian retail firms, no sample size increase could support H2. For UK retail firms, a sample size of 90 firms would produce a $p$-value below 10\%, supporting H2. However, for Australian and UK transportation firms, even if the sample size increased to 62 (the US sample size), $p$-values would be 0.35 or higher.

${ }^{34}$ Five years post-IFRS makes a seven-year difference. To put this in perspective, in our examination of lease lengths for $\mathrm{H} 3$, we find that, in 2007, Australia had a weighted-average lease term in retail and transportation of 3.8 and 3.3 years respectively, while in the UK the terms are 7.6 and 4.8 years. Therefore most leases will have turned over in this interval.

${ }^{35}$ To address testing power, we assess the effect of sample size in cases where the sign of the difference supports H2. For UK versus Canadian retail firms, even sample sizes of 164 firms in each country (the US sample size) would not yield a significant difference at 10\%. In transportation, tripling (doubling) the sample size would produce $p$-values less than $10 \%$ for Australia (UK) versus Canada.
} 
tests. Neither the time-series tests nor the difference-in-differences tests reveal statistically significant changes in capital lease use that could be attributed to IAS17 omitting bright lines. The addition of control variables for firm-specific motives, as with $\mathrm{H} 1$, does not change the overall inferences available from the univariate analysis. ${ }^{36}$

Overall, in our time-series and difference-in-differences tests using Australian and UK firms' switch to IAS17 as the test cases, we cannot conclude that removing bright lines materially affected companies' lease classification decisions. We base our inference on results that are logically inconsistent with $\mathrm{H} 2$. In retail, UK firms report the lowest capital lease use of any country, even after IAS17. In Australia, capital lease use changes in opposite directions in the two industries post-IFRS, with retail declining while transportation increases.

We report a final test of $\mathrm{H} 2$ in Table 6, with a different design from our earlier tests. Here we exploit the fact that, in the IFRS transition year, firms must restate their opening balance sheets to conform to IFRS. We compare lease balances reported the prior year under domestic GAAP to the same leases under IAS17. This test holds the underlying contracts constant and varies only the reporting regime. If removing bright-line guidance is effective in promoting lease capitalization, we will observe that firms reclassify operating leases to capital leases. In contrast, if the lack of guidance permits companies to be more aggressive, we could observe reclassification from capital to operating leases. Because this test does not require consistent time periods, we use 2011 data for Canada, alongside 2005 data for Australia and the UK.

For these tests, we first identify companies whose capital lease balances differ between the domestic GAAP and IAS17 representations of the same data. We then read the note disclosures for the transition year to ascertain the reason for the change. We find several technical reasons, unrelated to a greater emphasis on the general principle or the removal of bright lines, and code these separately as "technical" versus "guidance." Canadian retailer, provides an example of a guidance disclosure: "Under previous GAAP, the Company classified a lease as operating or finance based on quantitative 'bright-line' tests. Under IFRS, the assessment must be made based on a qualitative analysis of the risks and rewards" (Canadian Tire, 2011, 141). ${ }^{38}$ Interestingly, this quote reveals that the brightline guidance in prior domestic GAAP obscured the principle for this company, because Canada's domestic standard stated precisely the same risks and rewards principle as IAS17.

\footnotetext{
${ }^{36}$ We searched for contemporaneous tax law changes relating to leases in all our countries, because these could confound time-series tests. We found a UK tax law that could increase capital lease use and no changes in other countries. The UK Finance Act 2006 brought in "long funding leases" for plant and machinery meeting certain conditions, reported in the Business Leasing Manual (http://www.hmrc.gov.uk/leasing/blm1. pdf, accessed Jan. 23, 2013). The key condition relevant to our study is that a lease that a company reports as a finance lease under GAAP qualifies as a long funding lease for tax purposes. Before this Act, UK tax authorities treated nearly all leases as operating. Capital leases front-load expenses relative to operating leases, a clear tax advantage. By tying the advantageous tax treatment to financial reporting, the UK tax authorities may have influenced lease reporting to shareholders.

37 The technical differences include an IFRS requirement that land and buildings be evaluated separately, differing treatment of lease inducements and sale-leaseback transactions, and a test in IAS17 for assets specialized to the lessee.

${ }^{38}$ Other examples of such wording include: "IFRS is less prescriptive" (Stylo plc, 2008, 49); and “... quantitative guidance to facilitate lease classification was not provided ...” (Qantas, 2005, 136).
} 
In Panel A of Table 6, we note that 18 firms (14.6\% of sample firms transitioning to IFRS) reclassified capital leases for technical reasons and nine firms $(7.3 \%)$ did so due to the removal of bright-line guidance. In all nine guidance cases, firms capitalized additional leases; no firms reclassified existing capital leases to operating. Thus we find no support in this context for less precise standards leading to more aggressive accounting choices. We do, however, find qualitative support for the idea that eliminating bright lines can promote the use of capital leases.

Table 6 Panel B reports the average proportion of capital leases as a percentage of total lease commitments. The "Dom. GAAP" column reports capital lease use under domestic GAAP; "IFRS: Guidance" reports the average, including guidance-related changes but excluding technical IFRS changes; and "IFRS: All" reports the average including all IFRS changes. The key comparison is the difference between Dom. GAAP and IFRS: Guidance; it represents the incremental capital lease classification due to the omission of bright lines. Australian retail and UK transportation firms have no reclassifications. Australian transportation increases from 40.0 to $40.7 \%$. Canada retail shows the largest change, from 2.9 to $5.6 \%$; Canada transportation increases from 7.9 to $8.0 \%$; and UK retail increases from 0.7 to $1.1 \%$.

To assess the economic significance of the changes in Table 6, Panel B, we compare these changes to the decrease that Imhoff and Thomas (1988) observed for US highlease firms following FAS13: a median decline in capital leases of $6.8 \%$ of nonlease assets. Across our sample firms in Australia, Canada, and the UK, the capital lease increase due to removing bright lines averages $0.3 \%$ of nonlease assets; the median firm in each country-industry had no increase. ${ }^{39}$

We conclude three things from the transition-year analysis in Table 6: (1) removing bright lines did not encourage firms to reclassify capital leases as operating; (2) removing bright lines did encourage some firms to reclassify operating leases as capital, consistent with $\mathrm{H} 2$; and (3) the magnitude of such reclassifications is relatively small in economic terms.

\subsection{Tests of H3: eliminating the lease-term bright line promotes longer operating lease terms}

We now turn to our tests of specific features of operating leases that may indicate transaction structuring, beginning with the lease term. In 2003, Australia, Canada and the US each had a bright-line criterion for lease terms, while the UK did not. Between 2003 and 2007, Australia adopted IFRS, and so eliminated bright lines. If companies structure their leases to avoid the bright-line test, then we expect to find shorter operating lease terms in regimes with the bright line than in regimes without. Due to limitations of the UK disclosure pre-IFRS discussed in Section 3.3, we cannot estimate 2003 lease terms in the UK. We therefore test Australia's change from 2003 to 2007 and compare Australia and the UK to Canada and the US in 2007.

Ideally, we would want to compare lease terms to the underlying assets' useful lives. Since we do not have data on the leased assets' lives, we rely on within-industry analysis and a maintained assumption that similar assets (in our industries: premises or vehicles) will have similar useful lives across regimes.

\footnotetext{
${ }^{39}$ Our analysis is not tabulated but is available on request from the authors. The Imhoff and Thomas (1988) result appears on p. 293, Table 2 Panel B.
} 
Given that assumption, we hypothesize that operating lease terms will be shorter on average for companies facing a useful-life bright line.

Table 7 Panel A shows the average operating lease term across firms, by country, industry, and year, using the weighted-average lease term described in Section 3. The data requirements for estimating lease terms reduce our available observations slightly, relative to the numbers reported in Table 1. In Panel B, we report tests of H3: that firms in regimes with a bright line relating to the useful life will report shorter operating lease terms. For ease of exposition, we test the opposite of the stated hypothesis.

From Panels A and B, we observe that under IAS17, the UK has the longest lease terms in both industries, with significant differences from Canada and the US in retail. It is intriguing to conjecture that the historical lack of this bright line led UK firms to contract for longer terms in their operating leases than their industry peers in other countries, but lacking sufficient data pre-IFRS in the UK, this remains only a conjecture. Australia, on the other hand, has the shortest lease terms in both industries in 2007, significantly so in retail. Australia experienced a small but statistically insignificant increase in average lease term after adopting IAS17. The US, whose lease standards did not change, reported a similar small increase in retail. The mixed pattern in comparisons of Australia and the UK versus Canada and the US does not support a general

Table 7 Weighted-average Operating Lease Term, by Country, Industry, and Period, and Tests of H3

\begin{tabular}{|c|c|c|c|c|c|c|}
\hline \multirow{2}{*}{$\begin{array}{l}\text { Industry } \\
\text { Country } \backslash \text { Year }\end{array}$} & \multicolumn{3}{|l|}{ Retail } & \multicolumn{3}{|c|}{ Transportation } \\
\hline & 2003 & 2007 & $\mathbf{N}$ & 2003 & 2007 & $\mathbf{N}$ \\
\hline Australia & 3.7 & 3.8 & 23 & 3.2 & 3.3 & 11 \\
\hline Canada & 4.7 & 4.7 & 20 & 3.8 & 3.5 & 5 \\
\hline UK & N/A & 7.6 & 39 & N/A & 4.8 & 9 \\
\hline US & 4.7 & 4.9 & 163 & 4.5 & 4.1 & 59 \\
\hline
\end{tabular}

Panel B: Tests of H3 - Regimes without versus with a bright line for useful life

$\begin{array}{llll} & \text { Prediction } & \text { Retail } & \text { Transportation } \\ \text { AUS-2007 - AUS-2003 } & (+) & 0.1 & 0.1 \\ & & (0.85) & (0.93) \\ \text { AUS-2007 - CDA-2007 } & (+) & -0.9 & -0.2 \\ & & \mathbf{( 0 . 0 7 )} & (0.73) \\ \text { AUS-2007 - US-2007 } & (+) & -1.1 & -0.8 \\ \text { UK-2007 - CDA-2007 } & (+) & \mathbf{( 0 . 0 2 )} & (0.20) \\ & & 2.9 & 1.3 \\ \text { UK-2007 - US-2007 } & (+) & (\mathbf{0 . 0 0 1 )} & (0.38) \\ & & 2.7 & 0.7 \\ & & (<\mathbf{0 . 0 0 0 1}) & (0.37)\end{array}$

Table 7 presents our tests of H3: firms in regimes with no bright-line criterion for the lease term have longer operating lease terms than firms in regimes with such a criterion. We test H3 using cash-flow-weighted average operating lease term, as defined in Appendix, and include all firms that have operating lease activity in both 2003 and 2007 in this analysis. In Panel A, we tabulate the lease term measure within sample countries, industries, and periods. Panel B tabulates the time series and cross-sectional tests of $\mathrm{H} 3$, reporting the difference in mean values between the two regimes, and two-tailed $p$-values for t-tests of the difference in parentheses. Bold indicates a $p$-value below 0.10 , while bold italics indicate both a $p$-value below 0.10 and direction consistent with the stated alternative hypothesis 
conclusion that removing the lease-term bright line caused companies to write operating leases of longer duration. Rather, the data suggest that past practice regarding lease contract length continued following adoption of IAS17.

\subsection{Tests of H4: eliminating the present-value bright line reduces use of contingent rentals}

Next, we consider whether removing the present-value bright line reduces transaction structuring via contingent rentals. In 2003, all of our sample countries had a $90 \%$ bright-line criterion, and all excluded contingent rentals from minimum lease payments. In 2005, Australia and the UK adopted IAS17, which has no bright line. We therefore look for cross-country differences in 2007 and pre- versus post-IFRS differences in Australia and the UK. As discussed in Section 3, Canada has insufficient data to test $\mathrm{H} 4$, so our cross-country tests are limited to comparing Australia and the UK to the US. If removing this bright line causes companies to use fewer contingent rentals, we should find US companies in 2007 using more contingent rentals than companies reporting under IAS17, and Australian and UK companies reducing their use of contingent rentals between 2003 and 2007.

Panel A of Table 8 shows the average contingent proportion of operating lease expense by country, industry, and period, and Panel B reports associated statistical tests. As was true for $\mathrm{H} 3$, we lose observations due to unavailable data, relative to the samples reported in Table 1 .

We compare post-IFRS Australia in time-series with Australian domestic GAAP, and in cross-section with the US in 2007. The time-series tests in both industries are statistically insignificant, and their direction is opposite the prediction. The statistically significant difference versus the US in retail is opposite the hypothesized direction, refuting $\mathrm{H} 4$. The comparison against the US in transportation has the hypothesized direction but is not statistically significant. In the UK, as in Australia, both industries increased their use of contingent rentals post-IFRS, opposite prediction, though neither is statistically significant. This provides no support for H4. The sole piece of significant supporting evidence for $\mathrm{H} 4$ in our tests is the UK versus US comparison in transportation in 2007. Tempering this, however, are the facts that a similar significant difference existed in transportation before IFRS eliminated the bright line and that we fail to find an analogous result in retail. In sum, we fail to find support for $\mathrm{H} 4$, that removing the present-value bright line reduced transaction structuring via contingent rentals.

\section{Discussion and conclusion}

The SEC, FASB, and IASB all promote the idea that writing standards to emphasize principles - and without bright-line tests - can reduce transaction structuring and lead to better financial reporting ( SEC 2008; FASB 2010). Our research tests the effectiveness of these two standard-setting tools in practice, by examining whether either one affects companies' use of capital leases or the structure of their operating leases.

A strength of our design is its replication of analysis across two lease-intensive industries, retail and transportation, and across multiple regimes. We study four countries and two periods, chosen for variety in lease accounting regimes, with minimal variation on 
Table 8 Operating Lease Contingent Rentals, by Country, Industry, and Period, and Tests of H4

\begin{tabular}{llllllll}
\multicolumn{2}{l}{$\begin{array}{l}\text { Panel A: Average contingent rentals as a percentage of total rentals, by country, industry, and year } \\
\text { Industry }\end{array}$} & Retail & \multicolumn{5}{c}{ Transportation } \\
Country $\backslash$ Year & $\mathbf{2 0 0 3}$ & $\mathbf{2 0 0 7}$ & $\mathbf{N}$ & $\mathbf{2 0 0 3}$ & $\mathbf{2 0 0 7}$ & N \\
Australia & $20.3 \%$ & $26.0 \%$ & $22 / 21$ & $17.1 \%$ & $23.9 \%$ & $9 / 10$ \\
UK & $11.2 \%$ & $15.8 \%$ & $38 / 36$ & $10.8 \%$ & $11.7 \%$ & $9 / 8$ \\
US & $15.3 \%$ & $14.4 \%$ & $154 / 156$ & $29.1 \%$ & $30.6 \%$ & $58 / 59$
\end{tabular}

Panel B: Tests of H4 - Regimes without versus with a bright line for fair value

$\begin{array}{llcc} & \text { Prediction } & \text { Retail } & \text { Transportation } \\ \text { AUS-2007 - AUS-2003 } & (-) & 5.7 \% & 6.8 \% \\ & & (0.27) & (0.45) \\ \text { AUS-2007 - US-2007 } & (-) & 11.6 \% & -6.7 \% \\ & & \mathbf{( 0 . 0 0 1 )} & (0.29) \\ \text { UK-2007 - UK-2003 } & (-) & 4.6 \% & 0.9 \% \\ & & (0.15) & (0.91) \\ \text { UK-2007 - US-2007 } & (-) & 1.4 \% & -18.9 \% \\ & & (0.60) & (\mathbf{0 . 0 1})\end{array}$

Table 8 presents our tests of H4: firms in regimes with no bright-line criterion for the present value of minimum lease payments use fewer contingent rentals in their operating leases than firms in regimes with such a criterion. We include all firm-years in Australia, the UK, and the US that have the necessary data. We exclude Canada because operating lease expense is rarely disclosed. We test $\mathrm{H} 4$ using average contingent rentals, as defined in Appendix. In Panel A, we tabulate average contingent rentals within sample countries, industries, and periods. Panel B tabulates the time series and cross-sectional tests of H4, reporting the difference in mean values between the two regimes and two-tailed $p$-values for t-tests of the difference in parentheses. Bold indicates a $p$-value below 0.10 , while bold italics indicate both a $p$-value below 0.10 and direction consistent with the stated alternative hypothesis

non-accounting traits. We examine the extent of capital lease use across countries, through time within countries, and within firms. We also examine operating lease traits that relate to bright-line tests: the lease term and the use of contingent rentals. We find significant differences in leasing structure and activity across countries, industries, and periods, but these differences, taken together, do not support that the two standard-setting tools substantially influence lease accounting decisions. We find instances where these tools appear to have the intended effect, particularly in our analysis of the IFRS transition year, but the instances are not widespread and their overall economic impact is small.

Imhoff and Thomas (1988) provide compelling evidence that US companies substantially changed their contracts after FAS13. This fact undoubtedly contributes to standard-setters' concerns, because structured transactions challenge the notion that accounting depicts economic events and circumstances in a neutral way. We believe that the lack of a symmetric result when IFRS eliminated bright lines may be due to preparers and auditors carrying forward old practices, as long as the practices do not directly conflict with IFRS. The IFRS GAAP hierarchy supports seeking guidance from other jurisdictions and accepted practice on matters where IFRS is silent. ${ }^{40}$

\footnotetext{
${ }^{40}$ IAS8, paragraphs 7-12.
} 
Limiting our analysis to two industries and four countries raises concern about generalizability, although this concern is complicated by the fact that we find mainly null results on our stated hypotheses. Therefore a lack of generalizability for our results requires that these two standard-setting tools be effective in other industries or other accounting regimes. We cannot rule out this possibility. We believe, however, that it would provide little comfort to standard-setters to know that these tools may work in industries where leasing is less central to the business, but not in industries where leased assets are core parts of the business activity. Furthermore, prior research ranks our four countries among the strongest accounting and auditing enforcement regimes in the world. We therefore would find it surprising if these standard-setting tools were effective in weaker enforcement regimes.

Our goal in this research is to explore how specific differences in accounting standards affect reporting outcomes. Despite choosing countries to minimize the influence of other contextual factors, we find local differences dominate the effects of accounting standards. We identify two local features with potential to impact leasing decisions: (1) Australian firms tend to use hire purchase contracts more than firms in other countries, causing higher recorded capital leases; and (2) the 2006 UK Finance Act may have caused UK firms to use more capital leases, independent of the move to IFRS. This naturally leads to further questions: which local differences matter, and should they, under a principles perspective, result in different accounting outcomes? Candidate differences for future investigation include book-tax conformity and differences in tax law, local differences in property law or contract law that affect tenants' rights, internationalization of the leasing market (e.g., in transportation equipment), and typical contractual arrangements (e.g., hire purchase contracts).

We do not interpret our results as indicating that standard-setters should abandon principles in setting accounting standards or that they should embrace bright-line tests. Rather, our results suggest that neither relying on accountants to exercise professional judgment to apply a broad principle in a context where bright-line tests have taken hold, nor removing those bright-line tests from standards, necessarily lead to observable differences in outcomes, even in some of the best enforcement regimes in the world. We study only the lease context; extensions to other contexts in which bright lines have defined practice, such as majority voting rights and control, could be an avenue for future research.

With the lease accounting standards released in 2016 (IFRS 16: "Leases"; FASB Topic 842: "Leases"), the boards change the principle behind lease accounting from the "transfer of risks and rewards" for an entire leased asset to the "right of use" for part of the asset's productive capacity. The boards justify the change as better maintaining faithful balance sheet representation. With this change in principle, the role of professional judgment shifts from determining whether the lease should be capitalized to determining the capitalized asset and liability values.

Our findings contribute to debates about principles versus rules and about the level of detailed guidance in accounting standards. We find that explicitly including the principle in the standard did not materially affect lease capitalization outcomes. We find no evidence to suggest that removing bright-line guidance from the standard led to more aggressive avoidance of capital leases or caused firms to alter the structure of operating leases. We find limited evidence of firms classifying more leases as capital after the removal of bright line guidance. Overall, we conclude that the benefits of principles-focused standards are elusive. 
Acknowledgements The authors are grateful to Catalina Anghel, Vishal Baloria, Joseph Cheng, Andrea Down, Kaleab Mamo and Deanna Qi for excellent research assistance. For helpful comments, we thank seminar participants at the Universities of Georgia, Exeter, Toronto and Waterloo, at Bristol and Temple Universities, at the London School of Economics and Nanyang Technological Institute and conference participants at the 2012 AAA-IAS meeting, 2012 CAAA annual meeting and 2015 EAA annual congress. We thank Yasmine Chahed, Changling Chen, Mark Clatworthy, Bjorn Jorgensen, Duane Kennedy, Giovanna Michelon, Bradley Pomeroy, Peter Pope, Eddie Riedl, Roger Silvers, Kim Trottier, and Christine Wiedman, along with anonymous reviewers and Richard Sloan (the editor), for detailed comments that have improved the paper. All errors and omissions are ours. Earlier versions of this paper circulated under the title "Principles, Rules, Bright Lines and Transaction Structuring: A CrossRegime Study of Lessees." We gratefully acknowledge funding provided by the EY Professorship at the University of Waterloo and the Social Sciences and Humanities Research Council of Canada [grant \#410-2010-0503].

\section{Appendix}

Open Access This article is distributed under the terms of the Creative Commons Attribution 4.0 International License (http://creativecommons.org/licenses/by/4.0/), which permits unrestricted use, distribution, and reproduction in any medium, provided you give appropriate credit to the original author(s) and the source, provide a link to the Creative Commons license, and indicate if changes were made.

Variable definitions

\section{Leasing outcomes}

Capital lease use

Weighted-average operating lease term

Proportion of a given firm-year's total undiscounted lease commitments that arise from capital leases; constructed from data hand-collected from annual reports and Compustat.

Weighted average of digits $[1,2, \ldots \mathrm{T}]$, which represent years into the future in which a given firm-year reports operating lease cash flows, with the weight equal to the cash flow for that future year; constructed from hand-collected data from annual reports and Compustat.

Operating lease contingent One minus [the ratio of the one-year-ahead operating lease commitment rentals reported in year $t-1$, to the rental expense in year $t$, for a given firm-year; constructed from hand-collected data from annual reports and Compustat.

\section{Test variables}

AUS, CDA, UK, US

Post

Indicator variables for Australia, Canada, the UK, and the US, respectively. Indicator variable for post-2005 period.

\section{Control variables}

Size

Lev

Natural log of total assets at the beginning of the year; from Compustat.

Profit

Ratio of long-term borrowing to total assets at the beginning of the year; from Compustat.

Average of current and the past four years' [earnings before interest and taxes, scaled by beginning total assets]; from Compustat.

Var

Standard deviation of current and the past four years' [earnings before interest and taxes, scaled by beginning total assets]; from Compustat.

PPE

Ratio of nonleased fixed assets to total assets at the beginning of the year; from Compustat.

Growth

Percentage change in total assets from the prior to the current year; from Compustat.

Big4

Indictor variable set equal to 1 if the auditor in a given firm-year was Deloitte, EY, KPMG, or PWC. 


\section{References}

Agoglia, C., Doupnik, T., \& Tsakumis, G. (2011). Principles-based versus rules-based accounting standards: the influence of standard precision and audit committee strength on financial reporting decisions. The Accounting Review, 86(3), 747-767.

Altamuro, J., Johnston, R., Pandit, S., \& Zhang, H. (2014). Operating leases and credit assessments. Contemporary Accounting Research, 31(2), 551-580.

Ashton, R. (1985). Accounting for finance leases: a field test. Accounting and Business Research, 15, $233-238$.

Australian Accounting Standards Board (AASB). (1998). Leases. Accounting standard no. 1008 (AASB1008). Victoria: AASB.

Beattie, V., Goodacre, A., \& Thomson, S. (1998). The impact of constructive operating lease capitalization on key accounting ratios. Accounting and Business Research, 28(4), 233-254.

Beattie, V., Goodacre, A., \& Thomson, S. (2000a). Operating leases and the assessment of lease-debt substitutability. Journal of Banking and Finance, 24, 427-470.

Beattie, V., Goodacre, A., \& Thomson, S. (2000b). Recognition versus disclosure: an investigation of the impact on equity risk using UK operating lease disclosures. Journal of Business Finance \& Accounting, 27(9\&10), 1185-1224.

Beattie, V., Goodacre, A., \& Thomson, S. (2006). International lease-accounting reform and economic consequences: the views of U.K. users and preparers. The International Journal of Accounting, 41, 75-103.

Beechy, T., \& Conrod, J. (2008). Intermediate accounting. Toronto: McGraw-Hill Ryerson.

Bennett, B., \& Bradbury, M. (2003). Capitalizing non-cancelable operating leases. Journal of International Financial Management and Accounting, 14(2), 101-114.

Bowman, R. (1980). The debt equivalence of leases: an empirical investigation. The Accounting Review, 55(2), 237-253.

Brown, P., Preiato, J., \& Tarca, A. (2014). Measuring country differences in enforcement of accounting standards: an audit and enforcement proxy. Journal of Business Finance \& Accounting, 41(1\&2), 1-52.

Canadian Institute of Chartered Accountants (CICA). (1979). Leases. CICA handbook-Accounting (CICA $H B)$, section 3065. Toronto: CICA.

Canadian Tire. (2011). 2011 Annual Report: Life in Canada for 90 Years. Toronto, ON, Canada: Author.

Cohen, J., Krishnamoorthy, G., Peytcheva, M., \& Wright, A. (2013). How does the strength of the financial regulatory regime influence auditors' judgments to constrain aggressive reporting in a principles versus rules-based accounting environment? Accounting Horizons, 27(3), 579-601.

DeFond, M. L., \& Hung, M. (2004). Investor protection and corporate governance: Evidence from worldwide CEO turnover. Journal of Accounting Research, 42(2), 269-312.

Donelson, D., McInnis, J., \& Mergenthaler, J. (2012). Rules-based accounting standards and litigation. The Accounting Review, 87(4), 1247-1279.

Ely, K. (1995). Operating lease accounting and the Market's assessment of equity risk. Journal of Accounting Research, 33(2), 397-415.

Financial Accounting Standards Board (FASB). (1976). Accounting for leases. Statement of financial accounting standards no. 13 (FAS13). Norwalk: FASB Available at http:/www.fasb.org/st/.

Financial Accounting Standards Board (FASB). (2010). Leases. Exposure draft,. Norwalk: FASB/IASB.

Financial Accounting Standards Board (FASB). (2013). Leases. Exposure draft. Norwalk: FASB.

Financial Accounting Standards Board (FASB). (2016). Leases. Topic 842. Norwalk: FASB.

Hope, O. (2003). Disclosure practice, enforcement of accounting standards and analysts' forecast accuracy: an international study. Journal of Accounting Research, 41(2), 235-272.

Imhoff, E., \& Thomas, J. (1988). Economic consequences of accounting standards: the lease disclosure rule change. Journal of Accounting and Economics, 10(4), 277-310.

Imhoff, E., Lipe, R., \& Wright, D. (1991). Operating leases: impact of constructive capitalization. Accounting Horizons, 5(1), 51-63.

Imhoff, E., Lipe, R., \& Wright, D. (1993). The effects of recognition versus disclosure on shareholder risk and executive compensation. Journal of Accounting, Auditing, and Finance, 8(4), 335-368.

Institute of Chartered Accountants in England and Wales (ICAEW). (1984). Accounting for leases and hire purchase contracts. Statement of standard accounting practice no. 21 (SSAP21). London: ICAEW.

International Accounting Standards Board (IASB). (2003). Accounting policies, changes in accounting estimates and errors. International Accounting Standard 8 (IAS8). London: IASB.

International Accounting Standards Board (IASB). (2013). Leases. Basis for conclusions exposure draft. London: IASB. 
International Accounting Standards Board (IASB). (2016). Leases. International Financial Reporting Standard 16 (IFRS16). London: IASB.

International Accounting Standards Committee (IASC). (1997). Leases. International Accounting Standard 17 (IAS17), London, England: IASC; 2003, revised and re-issued by International Accounting Standards Board (IASB). London: IASB.

Jamal, K., \& Tan, H. T. (2010). Joint effects of principles-based versus rules-based standards and auditor type in constraining financial managers' aggressive reporting. The Accounting Review, 85(4), 1325-1346.

Kershaw, D. (2005). Evading Enron: taking principles too seriously in accounting regulation. The Modern Law Review, 68(4), 594-625.

Livne, G., \& McNichols, M. (2009). An empirical investigation of the true and fair override in the United Kingdom. Journal of Business Finance \& Accounting, 36(1\&2), 1-30.

Maines, L., Bartov, E., Fairfield, P., Hirst, D., Iannoconi, T., Mallett, R., Schrand, C., Skinner, D., \& Vincent, L. (2003). Evaluating concepts-based vs. rules-based approaches to standard setting. Accounting Horizons, 17(1), 73-89.

Mergenthaler, R. (2009). Principles-based versus rules-based standards and earnings management. Working paper, University of Iowa.

Moody's Investors Service. (2006). Moody's Approach to Global Standard Adjustments in the Analysis of Financial Statements for Non-Financial Corporations - Part I. http://www3.nd. edu/ carecob/Apri1\%202007\%20Conference/Analytical\%20Adjustments\%20-\%20Part\%20I\%20 updated.pdf. Accessed 20 May 2014.

Mueller, G., Gernon, G., \& Meek, G. (Eds.). (1997). Accounting: An international perspective. Chicago: Richard D. Irwin.

Nelson, M. (2003). Behavioral evidence on the effects of principles- and rules-based standards. Accounting Horizons, 17(1), 91-104.

Nelson, M., Elliott, J., \& Tarpley, R. (2002). Evidence from Auditors about Managers' and Auditors' Earnings Management Decisions. The Accounting Review, 77(supplement), 175-202.

Nobes, C. (2011). IFRS practices and the persistence of accounting system classification. Abacus, 47(3), 267283.

Qantas. (2006). 2006 Annual Report: Attention to Detail. Mascot, NSW, Australia: Author.

Schipper, K. (2003). Principles-based accounting standards. Accounting Horizons, 17(1), 61-72.

Securities Exchange Commission (SEC). (2003). Study pursuant to section 108(d) of the Sarbanes-Oxley act of 2002 on the adoption by the United States financial reporting system of a principles-based accounting system. Washington, DC: SEC. Available at http:/www.sec.gov/news/studies/principlesbasedstand.htm. Accessed 12 June 2014.

Securities Exchange Commission (SEC). (2008). Final report of the advisory committee on improvements to financial reporting. Washington, DC: SEC. Available at http:/www.sec.gov/about/offices/oca/acifr.shtml. Accessed 30 Aug 2011.

Stylo plc. (2008). Annual Report and Accounts, 52 Weeks Ended 2 February 2008. Bradford, West Yorkshire, UK: Author.

Tweedie, D. (2008). Prepared Remarks of Sir David Tweedie, Chairman of the International Accounting Standards Board, at The Empire Club of Canada, Toronto. (April 25). http://www.ifrs. org/News/Announcements-and-Speeches/Documents/Sir_David_Tweedie_Empire_Club_Speech.pdf. Accessed 29 Jan 2014. 